\title{
The Implied Growth Rates and Country Risk Premium: Evidence from Chinese Stock Markets
}

\author{
Pengguo Wang ${ }^{1}$ \\ Xfi Centre for Finance and Investment \\ Exeter University Business School \\ Exeter EX4 4ST \\ UK \\ p.wang@exeter.ac.uk
}

\author{
Wei Huang \\ Nottingham University Business School China \\ wei.huang@nottingham.edu.cn
}

March 2014

\footnotetext{
${ }^{1}$ We are grateful to David Ashton, Shujie Yao, Maria Herrerias and the seminar participants in School of Contemporary Chinese Studies at University of Nottingham, UK and Exeter University. We also thank WIND Information Co., Ltd for providing us financial data in China. Corresponding author: Pengguo Wang, email: p.wang@exeter.ac.uk.
} 


\title{
The Implied Growth Rates and Country Risk Premium: \\ Evidence from Chinese Stock Markets
}

\begin{abstract}
Realized stock market returns are volatile and poor reflections of economic growth and investor expectations in China. In this paper, we estimate simultaneously the implied long run growth rate and cost of equity capital for listed Chinese firms over the period 2004-2012. We find that the implied mean growth rate in earnings is around $10 \%$ and the mean implied cost of capital is about $14.6 \%$. These suggest that the implied growth rates from companies' fundamentals are in line with the economic growth and the implied cost of capital is consistent with investors' expectations. Comparing with estimates for the US markets, we find that the mean country equity risk premium for this largest emerging market is about $6.5 \%$. Our study has important implications to the Chinese policy makers and international investors.
\end{abstract}

JEL Classification: G12 G15

Key Words: Long term growth, cost of capital, country risk premium 


\section{Introduction}

Common wisdom suggests that stock markets are barometers of economic performance for a country. However the two major stock indices in China, Shanghai and Shenzhen composite indices, seem to demonstrate a few signs about the phenomena of high economic growth and high expected equity returns over the last twenty years. In this paper, we show that the implied growth rates from Chinese companies' fundamentals are indeed inextricably linked to the economic growth. The implied cost of equity capital as a proxy of expected return is around 14.6\% over the period 2004-2012. The estimated country equity risk premium for this developed emerging market relative to the US equity market is significant, about $6.5 \%$ on average.

Expected equity return or cost of equity capital is generally regarded as the discount rate under which the current price of equity is equal to the present value of expected all future dividends. Investment decisions require an accurate estimate of firms' expected returns. Financial managers need an appropriate estimate of the cost of capital for capital budgeting. Cost of capital is also a key element in the regulation of privatized industries as a means of estimating a fair rate of return. Unfortunately it is not directly observable and there is no commonly accepted approach to estimate it. Academics and practitioners often use two proxies for expected returns: average long-run realized returns and implied cost of capital or internal rate of returns.

Estimating the expected rate of return is proved challenging, particularly in emerging stock markets, which are often characterized with short history, high expected returns and high volatilities (Harvey, 1995; Bekaert and Harvey, 1997, 2000; Stulz, 1999; Henry 2000). Considering the equity risk premium for the US and other developed countries being estimated 
between four to seven percent per annum over the last fifty years (Fama and French, 1997; Ibbotson Associates, 2006; Dimson, Marsh and Staunton, 2011; Damodaran, 2011), a rational investor has good reasons to require a rate of return of at least $10 \%$ in nominal term on average for investments in Chinese equity market. To justify this argument, let us look at the risk-free rate and country risk premium (Siegel and Thaler, 1997). Firstly, the average annual yield on the Chinese 10-year Treasury notes is about $3.54 \%$ along with $3.17 \%$ inflation rate over our sample period. Secondly, investors are expected to be compensated by an 'emerging country risk premium' above the risk premium in a developed capital market due to factors, such as China's economic reform, political risk, social stability and the stability of Chinese currency. Therefore, a very crude estimate would give us an expected rate of return of over $10 \%{ }^{2}$

Bekaert and Harvey (2003) argue that standard asset pricing models, such as the CAPM, are usually ill-suited in emerging markets due to dynamic developments in such markets. When integrating both local and foreign factors in the equation (see, Bekaert and Harvey, 1995; Bekaert, Harvey and Lumsdaine, 2002; Carrieri, Errunza and Hogan, 2007), evidence shows that neither local beta nor global beta shows a significant relationship with stock returns in China. Recently, Eun and Huang (2007) and Wang and Di Iorio (2007) document that firm factors such as size and book-to-market ratio have explanatory power to Chinese stock returns. ${ }^{3}$ However, it is shown that systematic risk is somehow negatively related to equity returns in down markets (Wong, Tan and Liu, 2006; Morelli, 2010). Nevertheless, realized returns have been seen as a very bad measure of expected returns in Chinese capital markets (Fernald and Rogers, 2002).

\footnotetext{
${ }^{2}$ A recent survey indicates a risk premium of $9.4 \%$ for Chinese equity investment (Fernandez, Aguirreamalloa and Corres, 2011). The average market risk premium used by academics, analysts and managers of companies are $8.9 \%$, $7.9 \%$ and $10.9 \%$ respectively.

${ }^{3}$ More recently, Hou, Karolyi, and Kho (2011) show that a multifactor model that includes factor-mimicking portfolios based on momentum and cash flow-to-price captures significant time-series variation in global stock returns, and has lower pricing errors and fewer model rejections than the global CAPM or a popular model that uses size and book-to-market factors.
} 
Elton (1999) argues that "realized returns are a very poor measure of expected returns" even in a well developed economy. Pastor, Sinha and Swaminathan (2008) suggest that "a high realized return often signals that the expected return is falling rather than that the expected return is high". Many investors are puzzled by the fact that stock market indices at the end of 2012 are more or less similar to those of ten years ago, although China's GDP growth has been witnessed at an average annual rate of more than 10 percent over the same period. ${ }^{4}$ The complications arise because over the long run aggregate earnings, the source of value for investments in equity, are a stationary fraction of GDP (Cornell, 2010). This implies that investors can expect aggregate earnings growth to match GDP growth in the long run.

Recent studies turn to estimating the implied cost of capital as a proxy for expected returns. One appealing feature of the implied cost of capital is that it does not rely on noisy realized stock returns. However, it relies on a specific valuation model and often an assumed growth rate in terminal valuations. As a consequence, the precision of estimates of the implied cost of capital is largely dependent on the assumed rate of perpetual growth rate (Claus and Thomas, 2001; Gebhardt, Lee and Swaminathan, 2001; Botosan and Plumlee, 2005). ${ }^{5}$ The only prior attempts to estimate simultaneously the implied cost of capital and growth rate appear in Easton, Taylor, Shroff and Sougiannis (2002), Easton (2004) and Ashton and Wang (2013). However, Easton et al (2002) and Easton (2004) report an implausibly high average growth rate and consequently a biased estimate of the cost of equity capital based on the US data. ${ }^{6}$

The purpose of this paper is twofold. Firstly, we employ the Ashton and Wang (2013) model to estimate simultaneously the implied growth rates and cost of equity capital for the

\footnotetext{
${ }^{4}$ Chairman of China SEC, Guo Shuqing, was forced to offer his interpretation to the public in March 2012.

${ }^{5}$ Attig et al. (2008) and Chen et al. (2009) examine the effect of corporate governance and large shareholders on the implied cost of equity capital in emerging markets.

${ }^{6}$ Ashton and Wang (2013) argue that their model relies on only one-year-ahead forecasts of earnings and is more robust to biases in forecasts of earnings by financial analysts.
} 
Chinese markets. We apply this model not only because the authors claim that the estimated implied growth rates are more realistic than other models, but importantly the model requires only one-year ahead of forecasts of earnings and earnings forecasts for Chinese firms are largely unavailable beyond one-year horizon. ${ }^{7}$ We also introduce a new database to the international researchers who are interested in the Chinese capital market. Secondly, we evaluate the implied country risk premium specific to the largest developed emerging economy, which has never been investigated in prior literature. Our findings are consistent with Bondt, Peltronen and Santabarbara (2010), which document that China's equity prices can be reasonably well modeled using conventional fundamentals, in particular corporate earnings.

We carry out our empirical investigations by partitioning our data in two ways: on a yearby-year basis and on an industry-by-industry basis. Unlike Ashton and Wang (2013), we use value-weighted rather than equally weighted regressions in our empirical investigations. ${ }^{8}$ Moreover, we believe it is more meaningful to express the growth rates and cost of capital in real terms. This is because worldwide, most regulators tend to think of either a cost of equity capital or an equity risk premium expressed in real terms (Sudarsanam et al, 2011). In contrast, the cost of capital and growth rate all are in nominal terms in prior literature. Based on available data from the Chinese capital markets, our estimation of the implied growth rates has a mean of just over $10 \%$ over the period $2004-2012$. This turns out to be around $7.6 \%$ in real terms on a yearby-year basis. The implied growth rates in our sample firms closely match our observations from the growth rates of the Chinese economy over this period. On the other hand, our estimation of the implied mean cost of capital is about $14.6 \%$ while the mean risk premium is around $11 \%$ in

\footnotetext{
${ }^{7}$ Prior literature (e.g. Easton et al. (2002) and Easton (2004)) relies on multi-period forecasts of earnings and such data is available from $\mathrm{I} / \mathrm{B} / \mathrm{E} / \mathrm{S}$ for the U.S markets.

${ }^{8}$ It is argued that value-weighted regressions generate better reliable results (Easton and Sommers, 2007).
} 
nominal terms on a year-by-year basis. The real mean cost of capital is about $11.8 \%$ when expected inflation is proxied by the geometric mean of the prior 5-year actual CPI inflation rate. After estimating the implied growth rates and cost of capital for the US capital markets over the same period, we investigate the difference between risk premia from the Chinese capital markets and that from the US capital markets. We find that the mean country risk premia are $6.54 \%$ and $6.38 \%$ in nominal and real terms respectively. The median country risk premia is about $5.6 \%$. The estimates on industry-by-industry basis are similar.

Our estimates are based on fundamental information about tradable A-shares. This is the common set of shares in the existing literature that investigates the return of equity in China (see, Eun and Huang, 2007; Wang and Di Iorio, 2007; Wong, Tan and Liu, 2006; Morelli, 2010). We argue that the estimated implied cost of capital can be viewed as an approximation for the cost of all equity capital including non-tradable shares. ${ }^{9}$ In particular, when we consider all common shares represent the same claims to cash flows, the cost of equity must be the same for all common equity shares. While liquidity may well be a priced factor, as argued by Bekaert, Harvey and Lundblad (2007) and others, the liquidity risk addressed in prior literature may not be particularly relevant to the non-tradable shares in China. ${ }^{10}$ First, the non-tradable shares are largely held by the government. In order to have control over companies, those shares are not intended to be for sale. In other words, the non-tradable shares are held by those that can be viewed as very long-horizon investors. Unexpected liquidity shocks may not exist unless the

\footnotetext{
${ }^{9}$ As of December 2012, there are 2,494 listed companies in China, within which 70 percent A-shares are tradable and listed in Shanghai or Shenzhen stock exchanges. Around 5\% of the listed companies also issue tradable Bshares, traded in US dollar or Hong Kong dollar, which were initially reserved only for foreign investors then became investable for domestic investors since 2001. State shares and legal person shares are not tradable. So called state shares are shares held by the central government, local government and institutions that authorised by the state. So called legal person shares are shares held by domestic legal entities and institutions which include stock companies, state-private mixed enterprises and non-bank financial institutions.

${ }^{10}$ Liquidity risk arises from situations in which a seller is willing to sell an asset at the market price but no buyer is going to accept the price or an asset cannot sell at its market price quickly.
} 
Chinese government changes regulations. Second, one can think that the non-tradable stocks have high equity duration, which is the cash-flow weighted average time period at which shareholders receive the cash flows from their investment in a company's shares (Leibowitz et al., 1989; Dechow et al., 2004). It is evidence that the dividend yield in China is much lower than that in most of the developed capital markets. It is expected that companies are growing fast and stocks will pay a large fraction of cash flows in the distant future. Esterer and Schroder (2011) show that companies with a low cost of capital exhibit a high equity duration. High-duration stocks have both lower expected and realized returns than low-duration equity. Hence the argument on the liquidity premium for non-tradable A-shares is not convincing. Third, equity reform in China has led to the Chinese listed firms towards a completely tradable A-shares market over the last decade.

To our knowledge, this is the first paper estimating the implied growth rates, expected equity return and implied country risk premium in the largest emerging market in a comprehensive fashion. Our study has important implications to Chinese policy makers when they set the target economic growth rate each year. An unrealistic target growth rate may not be supportable by companies' fundamentals. This research also helps international investors for investment decision making in the Chinese capital markets. They may need to quantify the country risk premium when they form their expectations on expected returns.

The rest of the paper is organized as followings. In Section 2, we introduce the Ashton and Wang (2013) model for the determination of the implied growth rates and cost of equity capital. Section 3 describes the sample in our analysis. Section 4 reports the empirical findings and evaluates China specific country risk premium. Finally Section 5 concludes the paper. 


\section{The Model}

In this paper, we employ recently developed model by Ashton and Wang (2013) to simultaneously estimate the implied long-run growth rate of future investment opportunities and cost of equity capital. Their model relies on three assumptions: capital markets are free of arbitrage opportunities; net dividends are equal to earnings subtracting changes in book values of equity (i.e. the clean surplus accounting identity, Ohlson, 1995); and firm values are determined by its investment policy not a distribution policy, or dividends are irrelevant in Miller and Modigliani (1961) framework.

In an arbitrage-free market, they show that the expected one-period-ahead earnings can be expressed in terms of current prices, earnings and book values of equity. This has an intuitive appeal since it has long been recognized that prices lead earnings and earnings are highly persistent as documented in prior empirical literature (Fama and French, 2006; Hou and Robinson, 2006; Weiss et al, 2008; Richardson et al, 2011). Specifically they show that

$E_{t}\left[e_{t+1}\right]=\delta_{1} P_{t}+\delta_{2} e_{t}+\delta_{3} b_{t}+\delta_{4} b_{t-1}$,

where

$E_{t}\left[e_{t+1}\right]:$ the expected one-period ahead earnings based on available information at time $\mathrm{t}$;

$P_{t}$ : equity price at time $\mathrm{t}$

$e_{t}$ : earnings at time $\mathrm{t}$;

$b_{t}$ : book value at time $\mathrm{t}$.

The implied long-run growth rate and cost of equity capital can then be respectively written as: 


$$
\begin{aligned}
& g=\frac{\left(1+\delta_{2}+\delta_{3}\right)+\sqrt{\left(1+\delta_{2}+\delta_{3}\right)^{2}-4\left(\delta_{2}-\delta_{4}\right)}}{2}-1, \\
& R-1=(1+g)\left(1+\frac{\delta_{1}}{1+g-\delta_{2}}\right)-1 .
\end{aligned}
$$

They also incorporate the concept of accounting conservatism in their estimations since Claus and Thomas (2001) and others argue that expected growth is affected by both the expectation of future economic rents and the conservative nature of accounting. Hence they modify their simple model to the extended model below:

$$
E_{t}\left[e_{t+1}\right]=\delta_{1}^{\prime} P_{t}+\delta_{2}^{\prime} e_{t}+\delta_{3}^{\prime} b_{t}+\delta_{4}^{\prime} b_{t-1}+\delta_{5}^{\prime} P_{t-1}
$$

The implied long-run growth rate and cost of equity capital can accordingly be respectively written as:

$$
\begin{aligned}
& g=\frac{1+\delta_{2}^{\prime}+\delta_{3}^{\prime}-\delta_{5}^{\prime}+\sqrt{\left(1+\delta_{2}^{\prime}+\delta_{3}^{\prime}-\delta_{5}^{\prime}\right)^{2}-4\left(\delta_{2}^{\prime}-\delta_{4}^{\prime}-\delta_{5}^{\prime}\right)}}{2}-1, \\
& R-1=(1+g)\left(1+\frac{\delta_{1}^{\prime}+\delta_{5}^{\prime}}{1+g-\delta_{2}^{\prime}}\right)-1 .
\end{aligned}
$$

While we employ equations (2) and (5) to estimate the implied long-run growth rate of future investment opportunities in the Chinese economy, we use equations (3) and (6) to estimate expected rates of returns for the Chinese stock market as well as the U.S stock market, and finally the country risk premium over our sample period.

\section{Sample Description}


We use data provided by WIND Information Co., Ltd, a leading integrated service provider of financial data, information and software in China. Our sample consists of the prices and accounting data in the Chinese Yuan at the end of the fiscal year, as well as Treasury note yields over the period 2004-2012. Accounting data in 2004 and 2005 are adjusted according to the current 2006 accounting rules. ${ }^{11}$ WIND compiles analysts' earnings forecasts for Chinese A shares listed companies from top 50 institutional fund investors in China, and year 2004 is the first year when such data became available. Following the prior literature, firms with negative book values are deleted and earnings are measured as net income before extraordinary items. Market capitalization is equal to the price per share multiplied by numbers of tradable A-shares. We use average institutional investor forecasts of earnings per share made around the corresponding reported prior-year earnings announcements so that such forecasts incorporate most recent financial reports information. To obtain reasonable numbers of individual institutional forecasts in calculating consensus forecasts, we use 90 day window around the beginning of the financial years (from 16 November to 15 February). ${ }^{12}$ Due to our main interest being in analysts' consensus expectations, institutional forecasts compiled by WIND are particularly suitable for our purpose. Each individual institutional forecast represents recommendation by one of the 50 institutions (either by an individual analyst or a team of analysts following the same firm within an institution). Compared to the average of individual analyst forecasts, using the average of the institutional forecasts avoid bias towards views of larger institutions that have more analysts following the same firm. As all forecasts made by analysts have a valid period of time, we restrict our sample to include forecasts that are still valid when calculating average forecasts. Further, new forecasts are used to update previous forecasts

\footnotetext{
${ }^{11}$ Financial years for all public listed companies in China are calendar years as required by the China Securities Regulatory Commission.

${ }^{12}$ On average, six institutional forecasts are used to calculate the consensus values.
} 
from the same institution to avoid double counting. All variables used in our estimation are divided by the number of shares in issue to reduce heteroskedasticity and increase comparability across time. The price-to-book ratio is measured by the market value of equity and the book value of equity at the end of the year. In constructing our data set, we omit firms in the extreme percentile of market-to-book ratio and return on book equity (ROE) (Khan and Watts 2009). ${ }^{13}$ We provide summary statistics in Table 1.

\section{< Insert Table 1 about here>}

In Panel A, we observe that the mean of the price-to-book ratio is 3.65, and return on equity is about 7 percent and the dividend yield is around 1 percent. To have a better idea about the evolutions of input variables over time, Panel B shows the means and medians of relevant variables by year. Panel C presents the correlation between variables. It shows that analysts' forecasts of earnings are highly positively correlated with current prices, earnings and book values. Our industry classification follows that of the China Securities Regulatory Commission.

\section{Empirical Results}

We carry out our empirical investigations by partitioning our data in two ways. First, we investigate the models on a year-by-year basis using cross-sectional regressions; we then investigate the models on an industry-by-industry basis using a time series cross-sectional regression. Following the prior literature, we use price per share measured three months after the

\footnotetext{
${ }^{13}$ Winsorizing the extreme percentiles does not change our main results.
} 
end of the fiscal year in our regressions to ensure that accounting information is known before the value is computed. ${ }^{14}$

In our time series analysis, we use book values as a deflator and value-weighted regressions when we estimate our parameters because Easton and Sommers (2007) find that using book value as a deflator and value-weighted regressions generate smaller biases than those from an equally weighted regression. The weights in a value-weighted regression are calculated as individual firm's equity prices multiplied by numbers of tradable A-shares divided by the total market capitalization of all tradable A-shares in the market. Following prior literature, we use analysts' earnings forecasts, i.e. one period ahead forecasted earnings $\left(f e p s_{t}\right)$ to proxy $E_{t}\left[e_{t+1}\right]$ in equations (1) and (4). Therefore we run the following two regressions to back out our estimates of the implied growth rate and cost of equity capital on a year-by-year basis: ${ }^{15}$

$$
\begin{aligned}
& \frac{\text { feps }_{t+1}}{b_{t}}=\delta_{3}+\delta_{1} \frac{P_{t}}{b_{t}}+\delta_{2} \frac{e_{t}}{b_{t}}+\delta_{4} \frac{b_{t-1}}{b_{t}}+\varepsilon_{t+1}, \\
& \frac{\text { feps }_{t+1}}{b_{t}}=\delta_{3}^{\prime}+\delta_{1}^{\prime} \frac{P_{t}}{b_{t}}+\delta_{2}^{\prime} \frac{e_{t}}{b_{t}}+\delta_{4}^{\prime} \frac{b_{t-1}}{b_{t}}+\delta_{5}^{\prime} \frac{P_{t-1}}{b_{t}}+\varepsilon_{t+1}^{\prime}
\end{aligned}
$$

In industry analysis, we employ the panel data methodology of Petersen (2009) to estimate two-way cluster-robust standard errors to correct for both time-series and crosssectional correlations. ${ }^{16}$

\subsection{Analysis on a year by year basis}

\footnotetext{
${ }^{14}$ We also ran all our models using just fiscal year end prices and found that there was little difference in the results. ${ }^{15}$ Since the error terms in our regression equations may be heteroskedastic, we use White (1980) corrections to the standard errors in our estimations.

${ }^{16}$ We find that our main results are not changed if we use a value-weighted regression as that in the year-by-year analysis.
} 
Our sample size varies over the nine years from a low of 593 firms in 2007 to a high of 1068 firms in 2012. The average number of annual observations is 801 . We regress forecasted one year ahead return on equity (ROE) on prices, earnings, lagged book values per share, and lagged prices all deflated by current book value to obtain the coefficients, $\delta_{i}$ and $\delta_{i}^{\prime}$ from equations (7) and (8). The parameter estimates in the regression for each year are shown in Table 2.

<Insert Table 2 about here>

In Panel A of Table 2, using the simple model based on equation (7) we observe that all of the $\delta_{1} \mathrm{~s}$ and $\delta_{2} \mathrm{~s}$ are positive as predicted. We also observe that $\delta_{1}$ is highly significant with regard to explaining one-year ahead earnings, confirming that prices lead earnings after controlling for current earnings and book values. We note that current earnings $\left(\delta_{2}\right)$ are also an important predictor of future earnings. Coefficients of both book values ( $\delta_{3}$ and $\delta_{4}$ ) are mostly insignificant. A similar phenomenon occurs when we examine the extended model in Panel B. However, the coefficient of current book value $\left(\delta_{3}^{\prime}\right)$ becomes significant in 5 of the 9 regressions, suggesting the role of book equity in the generation of future earnings.

In Table 3, we detail the estimates of growth rates, cost of capital and risk premia on a year by year basis, using both the simple model (Panel A) and the extended model (Panel B). Our estimates of the mean growth rates in the simple and extended model are $10.27 \%$ and $10.14 \%$ respectively. We also observe that the mean cost of capital $14.58 \%$ and mean risk premium $11.04 \%$ from the extended model are very similar to those from the simple model. We report risk premia based on a 10-year Chinese Treasury note yields as a proxy for the risk free 
rate. These suggest that the mean implied nominal growth rate of earnings for Chinese listed firms is in parallel with GDP growth, although the ex-post returns in the stock markets are highly volatile and somewhat inconsistent with the strong economic performance over this period.

<Insert Table 3 about here>

We note that the implied earnings growth rate has an ' $M$ ' shape, with the highest rate of $15.72 \%$ in 2007 and the lowest rate of $5.7 \%$ in 2004 and 2008 from Panel B. This appears consistent with two major Chinese stock indices being at their historical peak in 2007 and dramatic Chinese market correction during 2008. ${ }^{17}$ The implied cost of capital has a similar shape. Figure 1 illustrates the trend for our estimates in growth rates, cost of capital and risk premium. It shows clearly that the growth rate declined but the cost of capital increased so did the risk premium between 2009 and 2010, indicating a sign of economic recession. Between 2011 and 2012, the implied risk premium dropped by $3.5 \%$ as the implied cost of capital dropped by $3.3 \%$, while the implied growth rate roughly unchanged. This may be a sign of reduced uncertainties and the start of economic recovery.

$<$ Insert Figure 1 about here>

In Figure 2, we compare our estimates of the implied growth rate on earnings with an actual GDP growth rate and realizations of inflation one year ahead. It suggests that the overall correlation between the actual GDP growth rate and our implied growth rate of company earnings is over $80 \%$ although analysts are likely to be over optimistic in good time and over pessimistic in bad time. On the other hand, it is not surprising that the mean implied growth rate of listed companies is more volatile than the realized GDP growth rate as the real economy is

\footnotetext{
${ }^{17}$ Stock market fell by almost $60 \%$ as of the end of 2008 from the 2007 peak. This coincides with the international financial market crisis.
} 
more diversified than our sample portfolio. Such results clearly indicate that economic growth is associated with the expectations on earnings fundamentals of the listed firms. It also notes that the implied growth rate is highly correlated with next year realizations of CPI inflation rate with correlation about $80 \%$. This seems to indicate that the growth rate implied by analysts' forecasts of earnings has incorporated information about the expected inflation.

$<$ Insert Figure 2 about here>

\subsection{Analysis on an industry basis}

We repeat the above analysis on an industry-by-industry basis to estimate the implied growth rate and cost of equity capital. Appendix shows the detail industry classifications. We employ the panel data methodology of Petersen (2009) to estimate two-way cluster-robust standard errors to correct for both time-series and cross-sectional dependence. Our sample size varies across 13 industries, from a low of 96 firm-years in the Entertainment industry to a high of 4,119 firm-years in the Manufacturing industry. The average number of observations within each industry is about 560. Regressing one period ahead forecasted earnings on earnings, book value and lagged book value per share, and current and lagged prices, all deflated by book values for each industry based on equations (7) and (8), we obtain the regression coefficients in the two models and report regression coefficients by industry in Table 4 .

<Insert Table 4 about here>

Again we observe that the dominant explanatory variables are price, $\left(\delta_{1}\right.$ and $\left.\delta_{1}^{\prime}\right)$ and earnings $\left(\delta_{2}\right.$ and $\left.\delta_{2}^{\prime}\right)$, confirming that prices lead earnings and earnings are highly persistent. All 
13 parameter estimates of the coefficient of the current price and earnings are positive and stochastically significant.

\section{$<$ Insert Table 5 about here>}

Table 5 details the implied growth rates, cost of capital and risk premium of the individual industries over the sample period. In Panel A we observe a mean cost of capital of $13.47 \%$ and a mean growth rate of $10.23 \%$ for the simple model. The mean cost of capital and mean growth rate for the extended model, in Panel B are $12.26 \%$ and $8.61 \%$ respectively. It shows that the Construction industry has the highest growth rate and the Agriculture industry has the lowest. The highest growth rate in the construction sector reflects the country heated real estate market and the massive infrastructure development during our sample period. In Table 5, Panel B we see that the average risk premium from the extended model is $8.8 \%$ and the median risk premium is $8.1 \%$.

\subsection{The implied real growth rate and real cost of capital}

Given the relative high inflation in most of the emerging markets, the growth rates and cost of capital may be more meaningfully expressed in real terms (Reinhart and Rogoff, 2010; Dimson, Marsh and Staunton, 2011). Worldwide, most regulators prefer to express a cost of equity capital in real terms (Sudarsanam et al, 2011). We estimate the expected real rate of return and the real expected risk premium according to the Fisher inflation parity ${ }^{18}$. We adopt the geometric mean of the prior 5-year CPI inflation rate as a proxy of the expected inflation rate.

\footnotetext{
${ }^{18}$ In other words, expected real rate of return $=(1+$ expected nominal rate of return $) /(1+$ expected rate of inflation $)$ -1 , and real expected risk premium $=$ expected nominal premium $/(1+$ expected inflation rate $)$.
} 
Accordingly, in Tables 6 and 7 we present estimates of the real expected return on equity and the real growth rate in earnings.

$<$ Insert Table 6 about here>

Table 6 shows that both the simple model and extended model generate similar results based on a year-by-year analysis. The mean and median implied real growth rates are $7.64 \%$ and $7.60 \%$ respectively for the extended model. The mean and median implied real costs of capital are $11.77 \%$ and $11.98 \%$ respectively. The highest real growth rate is $14.73 \%$ and the highest real cost of capital is $17.96 \%$ when stock indices were at their peak in 2007 . On the contrary, the lowest real growth rate is $2 \%$ and the lowest real cost of capital is $5.69 \%$ when the financial crisis started worldwide in 2008 and the actual CPI inflation rate was the second highest over our sample period.

<Insert Table 7 about here>

Table 7 shows that the implied real growth rates and real cost of capital based on an industry-by-industry analysis. The mean implied real growth rates are $6.32 \%$ and $4.33 \%$ for the simple and extended models respectively. The mean implied real cost of capital is $10.46 \%$ for the simple model and $9.24 \%$ for the extended model. The Panel B for the extended model shows that the Construction and Mining industries have the highest and double digits implied growth rates and cost of capital. This is consistent with our earlier results in Table 5.

\subsection{Country risk premium}

A country risk premium reflects the extra risk relative to a mature reference market premium in a specific market. Existing literature often uses the US ex-post equity risk premium 
as a baseline when estimating a country risk premium (Stulz, 1999; Dimson et al, 2002, 2008). The adjustments are based on sovereign bond ratings, foreign exchange risks, as well as relative volatilities between government bond and equity prices for such models. Given the difficulty in estimating sovereign bond ratings and foreign exchange risks, in this paper we define country risk premium as the difference between the implied risk premium from the Chinese capital markets and that from the US capital markets. In contrast to all existing studies, our estimates of the country equity risk premium are based on the implied cost of capital.

In order to estimate the implied country risk premium, we first repeat our analysis in Section 4.1 based on the US data over the same sample period, 2004-2011. ${ }^{19}$ The sample consists of prices and accounting data in the intersection of the Centre for Research in Security Prices (CRSP), Compustat and the Institutional Brokers Estimate System (I/B/E/S). The adjusted numbers of shares outstanding and adjusted price at the end of the fiscal year, and adjusted price of equity 3 months after the fiscal year-end are collected from CRSP. Relevant accounting data is collected from Compustat. Consistent with prior studies, we use median consensus forecasts of earnings per share at the first month after the corresponding $\mathrm{I} / \mathrm{B} / \mathrm{E} / \mathrm{S}$ reported prior-year earnings announcements. For comparison, we provide sample descriptive statistics in Table 8.

\section{< Insert Table 8 about here>}

In Panel A, we observe that the mean of the price-to-book ratio is about 2.5 and the dividend yield is 2 percent. Panel B presents the correlation between variables. It shows that analysts' forecasts of earnings are highly positively correlated with current prices, earnings and book values. The sample size varies over the eight years from a low of 2453 firms in 2011 to a high of

\footnotetext{
${ }^{19}$ The implied growth rate and cost of capital can be similarly estimated on an industry-by-industry basis. However, it may not make much sense to compare country risk premium implied from the analysis since the industry classifications are very different across countries. 2012 data is incomplete when this paper is written.
} 
2763 firms in 2006. The average number of annual observations is 2640. Again, the regressions confirm that prices lead earnings and earnings are highly persistent. In Table 9, we detail the estimates of both nominal and real growth rates, cost of capital and the risk premia on a year by year basis, using the extended model. ${ }^{20}$ Panels $\mathrm{A}$ and $\mathrm{B}$ report the results in nominal terms and real terms respectively.

Our estimates of the mean implied growth rates in nominal term and real term are $4.19 \%$ and $1.52 \%$ respectively. The mean implied cost of capital in normal and real terms are $8.10 \%$ and $5.33 \%$ respectively. This is in line with prior studies (Easton, 2009). The mean implied risk premia are $4.24 \%$ in nominal term and $4.13 \%$ in real term. The risk premium (RP) is calculated relative to the yield on a 10-Year US government bond.

$<$ Insert Table 9 about here>

Finally, we report our estimates of the country equity risk premium in Table 10. Panels A and $\mathrm{B}$ show the results in nominal term and real term respectively.

<Insert Table 10 about here>

Columns 2 and 5 show the risk premia from the Chinese capital markets in both nominal and real terms in our sample period. Columns 3 and 6 report the equivalence of those from the US capital markets. As expected, the results show that the Chinese markets are much more volatile than the US markets. The standard deviations of the risk premium from the Chinese markets are about 3 times larger than those of the US market. Column 4 shows that the mean and median of country equity risk premia are $6.54 \%$ and $5.68 \%$ respectively over $2004-2011$ based on the nominal risk premia in China and the US. Column 7 shows that the mean and median of the country equity risk premia in real terms are very close to the nominal rates based results in

\footnotetext{
${ }^{20}$ The simple model generates very similar results.
} 
Column 4 as expected. We notice that the country risk premium is at its highest of $13.89 \%$ in 2007 when the implied risk premium peaked and fell to its lowest of $1.12 \%$ after the Chinese market experienced a dramatic correction during 2008.

\section{Conclusion}

It is generally agreed that the Chinese capital markets are much more volatile than most of the developed capital markets. The average realized return is a very poor proxy for expected returns, which are supposed to compensate the risks borne by investors. Moreover, the realized growth of the market indices is too volatile to be a plausible proxy of the growth of the Chinese economy. The performance of the two major Chinese stock indices is certainly disappointing to many investors over the recent decade while the country is evidenced with an extraordinarily high economic growth. The traditional asset pricing models are of limited use in determining the expected returns in this largest developed emerging capital market and do not help much in investors' decision making.

In this paper we apply a new methodology developed by Ashton and Wang (2013) for estimating the implied long run growth rate, the corresponding implied cost of equity capital and country equity risk premium. The subsequent implementation of the model generates estimates of the growth rates in earnings of just over $10 \%$ in nominal terms, and around $7.6 \%$ in real terms over the period 2004-2012. These are consistent with our observations on Chinese economic growth. Our estimation of the mean implied cost of capital is about $14.6 \%$ in nominal terms and the corresponding mean risk premium is around $11 \%$, which are consistent with market participants' expectations. Comparing the risk premia from the Chinese capital markets with those from the US capital markets over the same period, we find that there is a significant 
country risk premium. The mean and median country equity risk premia in the Chinese stock markets are about $6.5 \%$ and $5.6 \%$.

To our knowledge, we are among the first who analyze the implied growth rate and cost of capital for a major emerging stock market. Our study has important implications to the Chinese policy makers when they set target economic growth rate and international investors when they make investment decisions and estimate country risk premium in the Chinese capital markets. It is critical that growth targets are set and economic policies are supported by company earnings fundamentals as listed firms constitute an important part of the Chinese economy and the wealth of the nation. It is also imperative for international investors to have reliable estimates of company expected earnings growth and cost of capital since poor knowledge of these benchmark rates may lead to misinformed business decisions and often investment loss. 


\section{REFERENCES}

Ashton JD, Wang P (2013) Terminal valuations, growth rates and the implied cost of capital. Rev Acc Stud 18: 261-290.

Attig N, Guedhami O, and Mishra D (2008) Multiple large shareholders, control contests, and implied cost of equity. J Corp Financ 14: 721-737.

Bekaert G, Harvey C (1995) Time-varying world market integration. J Financ 50: 403-44.

Bekaert G, Harvey C (1997) Emerging equity market volatility. J Financ Econ 43: 29-77.

Bekaert G, Harvey C (2000) Foreign speculators and emerging equity markets. J Financ 55: 565 613.

Bekaert G, Harvey C (2003) Emerging markets finance, J Empir Financ 10: 3-55.

Bekaert G, Harvey C, and Lumsdaine RL (2002) Dating the integration of world equity markets. J Financ Econ 65: 203-47.

Bekaert G, Harvey C, and Lundblad C (2007) Liquidity and expected returns: lessons from emerging markets. Rev Financ Stud 20: 1783-1831.

Bondt GJ, Peltronen TA, and Santabarbara D (2010) Booms and busts in China's stock market: estimates based on fundamentals. The European Central Bank, working paper \#1032.

Botosan C, Plumlee MA (2005) Assessing alternative proxies for the expected risk premium. Account Rev 80: 21-53.

Carrieri F, Errunza V, and Hogan K (2007) Characterizing world market integration through time. J Financ Quant Anal 42:915-40.

Chen K, Chen Z, Wei K (2009) Legal protection of investors, corporate governance, and the cost of equity capital. J Corp Financ 15: 273-289.

Claus J, Thomas J (2001) Equity premia as low as three percent? evidence from analysts' earnings forecasts for domestic and international stock markets. J Financ 56: 1629-1666.

Cornell B (2010) Economic growth and equity investing. Financ Anal J 66: 54-64.

Damodaran A (2011) Equity risk premiums (ERP): determinants, estimation and implications. Working paper, Stern School of Business, New York University.

Dechow P, Sloan R, and Soliman M (2004) Implied equity duration: a new measure of equity risk, Rev Account Stud 9: 197-228.

Dimson E, Marsh P, and Staunton M (2008) Triumph of the optimists: 101 years of global investment returns, eBook. 
Dimson E, Marsh P, and Staunton M (2008) The worldwide equity risk premium: a smaller puzzle, Chapter 11 in the Handbook of the Equity Risk Premium, edited by R. Mehra, Elsevier. Dimson E, Marsh P, and Staunton M (2011) Credit Suisse global investment returns sourcebook 2011. Credit Suisse Research Institute, Zurich.

Easton PD (2004) PE ratios, PEG ratios, and estimating the implied expected rate of return on equity capital. Account Rev 79: 73-96.

Easton PD (2009) Estimating the cost of capital implied by market price and accounting data. Found Trends Account 2: 241-364.

Easton PD, and Sommers G (2007) Effect of analysts' optimism on estimates of the expected rate of return implied by earnings forecasts. J Account Res 45: 983-1016.

Easton PD, Taylor G, Shroff P, and Sougiannis T (2002) Using forecasts of earnings to simultaneously estimate growth and the rate of return on equity investment. J Account Res 40: $657-676$.

Elton E (1999) Expected return, realized return and asset pricing tests. J Financ 54: 1199-1220.

Esterer F, Schroder D (2011) The implied equity duration: empirical evidence for explaining the value premium? Working paper, Birkbeck College, University of London.

Eun CS, and Huang W (2007) Asset pricing in China's domestic stock market: is there logic? Pac-Basin Financ J 15:452-480.

Fama E, and French K (1992) The cross section of expected returns. J Financ 47(2): 427-465.

Fama E, French K (1993) Common risk factors in the returns on stocks and bonds. J Financ Econ 33: 3-56.

Fama E, French K (1997) Industry costs of equity. J Financ Econ 43: 153- 193.

Fama EF, French K (2006) Profitability, investment and average returns. J Financ Econ 82: 491518.

Fernald J, Rogers JH (2002) Puzzles in the Chinese stock market. Rev Econ Stat 84(3): 416-432.

Fernandez P, Aguirreamalloa J, and Corres L (2011) Market risk premium used in 56 countries in 2011: A survey with 6,014 answers. Working Paper-920, IESE Business School, University of Navarra.

Gebhardt W, Lee C, and Swaminathan B (2001) Toward an implied cost of capital. J Account Res 39: 135-176. 
Harvey C (1995) Predictable risk and returns in emerging markets. Rev Financ Stud 8(3): 773 816.

Hou K, and Robinson DT (2006) Industry concentration and average stock returns. J Financ 61: 1927-1956.

Henry PB (2000) Stock market liberalization, economic reform, and emerging market equity prices. J Financ 55(2): 529-564.

Ibbotson Associates. Stocks, bonds, bills and inflation, valuation edition 2006 yearbook.

Leibowitz M, Sorensen E, Arnott R, and Hanson H (1989) A total differential approach to equity duration. Financ Anal J 45(5): 30-37.

Miller M, Modigliani F (1961) Dividend policy, growth and the valuation of shares. J Bus 34: 411-433.

Morelli D (2012) Security returns, beta, size, and book-to-market equity: evidence from the Shanghai A-share market. Rev Quant Finance Acc 38:47-60.

Ohlson J (1995) Earnings, book values, and dividends in security valuation. Contemp Account Res 11: 661-687.

Pastor L, Sinha M, and Swaminathan B (2008) Estimating the intertemporal risk-return tradeoff using the implied cost of capital. J Financ 63: 2859-2897.

Petersen MA (2009) Estimating standard errors in finance panel data sets: comparing approaches. Rev Financ Stud 22: 435-480.

Reinhart CM, Rogoff KS (2010) Growth in a time of debt. Am Econ Rev 100: 573-578.

Richardson S, Tuna I, and Wysocki P (2010) Accounting anomalies and fundamental analysis: a review of recent research advances. J Account Econ 50:410-454.

Siegel J, Thaler RH (1997) The equity risk premium puzzle. J Econ Perspect 11: 191-200.

Stultz R (1999) Globalization, corporate finance and the cost of capital. J Appl Corp Financ 12(3): 8-25.

Sudarsanam S, Kaltenbronn U, and Park P (2011) Cost of equity for regulated companies: an international comparison of regulatory practices. discussion paper, competition Commission, UK. Wang Y, Di IorioA (2007) The cross-sectional relationship between stock returns and domestic and global factors in the Chinese A-share market. Rev Quant Finance Acc 29: 181-203.

Weiss D, Naik PA, and Tsai CL (2008) Extracting forward-looking information from security price: a new approach. Account Rev 83(4): 1101-1124. 
White H (1980) A heteroscedasticity-consistent covariance estimator and a direct test for heteroscedasticity. Econom 48: 817-838.

Wong KA, Tan RS, and Liu W (2006) The cross-section of stock returns on the Shanghai stock exchange. Rev Quant Finance Acc 26: 23-39.

Please delete Dimson et al. (2002)

Hou K., Karolyi GA, and Kho BC (2011) What Factors Drive Global Stock Returns? Fisher College of Business Working Paper No. 2006-03-009.

Khan M. Watts R. (2009) Estimation and Validation of a Firm-year Measure of Conservatism. J Account Econ, 48: 132-150. 


\section{Appendix: Industry Classification}

\begin{tabular}{|c|c|c|}
\hline & Industry Name & Industry Descriptions \\
\hline 1 & Agriculture & Agriculture; Forestry; Livestock; Fisheries; Related services \\
\hline 2 & Mining & $\begin{array}{l}\text { Coal Mining and Dressing; Oil and gas exploration; Ferrous Metals } \\
\text { Mining; Nonferrous Metals Mining and Dressing; Mining service }\end{array}$ \\
\hline 3 & Manufacturing & $\begin{array}{l}\text { Food processing; The food manufacturing; Manufacture of Beverages; } \\
\text { textile; Clothing and other fiber products manufacturing; Leather, fur, } \\
\text { feather and related products manufacturing; Timber Processing, } \\
\text { Bamboo, Rattan, Palm, Grass Products; Furniture Manufacturing; } \\
\text { Paper and paper products; Printing; Educational and Sports Goods; } \\
\text { Petroleum processing and coking; Chemical materials and chemical } \\
\text { products manufacturing; Manufacture of Chemical Fibers; Rubber } \\
\text { manufacturing; Plastic manufacturing; Electronic Components } \\
\text { Manufacturing; Electric Appliances manufacturing; Other electronic } \\
\text { equipment manufacturing; Non-metallic mineral products; Ferrous } \\
\text { metal smelting and rolling processing; Non-ferrous metal smelting and } \\
\text { rolling processing; Fabricated metal products; Ordinary Machinery } \\
\text { Manufacturing; Special equipment manufacturing; Transportation } \\
\text { equipment manufacturing; Electrical machinery and equipment } \\
\text { manufacturing; Instruments, Meters, Cultural and Office Machinery; } \\
\text { Pharmaceutical manufacturing; Bio-products }\end{array}$ \\
\hline 4 & Utilities & $\begin{array}{l}\text { Production and supply of electricity, steam, hot water; Gas production } \\
\text { and supply industry; Tap Water Production and Supply }\end{array}$ \\
\hline 5 & Construction & Civil Engineering Construction; Property Decoration \\
\hline 6 & Transportation & $\begin{array}{l}\text { Railway transport; Road transport; Water Transport; Air transport; } \\
\text { Transport Subsidiary Services; Other Transport; Warehousing }\end{array}$ \\
\hline 7 & Computers & $\begin{array}{l}\text { Communications and related equipment manufacturing; Computer and } \\
\text { related equipment manufacturing; Communication services; Computer } \\
\text { Application Services }\end{array}$ \\
\hline 8 & Wsale Retail & Wholesale trade of food, beverages, tobacco and household goods; \\
\hline
\end{tabular}




\begin{tabular}{|l|l|l|}
\hline & & $\begin{array}{l}\text { Energy, materials and machinery, electronic equipment, wholesale } \\
\text { trade; Other wholesale trade; Retail; Commercial Brokers and Agents }\end{array}$ \\
\hline 9 & Banking Insur & $\begin{array}{l}\text { Banking; Insurance; Securities and futures; Trust; Other financial } \\
\text { sector }\end{array}$ \\
\hline 10 & Real Estate & $\begin{array}{l}\text { Real estate development and management; Real Estate Management; } \\
\text { The Real Estate Broker }\end{array}$ \\
\hline 11 & Services & $\begin{array}{l}\text { Public facilities services; Professional, scientific research and services; } \\
\text { Food and beverage; Hotel and Guesthouse Accommodation; Tourism; } \\
\text { Sanitation, health care service industries; Leasing Services; Other } \\
\text { Social Services }\end{array}$ \\
\hline 12 & Entertainment & $\begin{array}{l}\text { Publishing; Radio, Film and Television; Dissemination of information } \\
\text { services; Other forms of communication, cultural industries }\end{array}$ \\
\hline
\end{tabular}


Figure 1: The Relation between Estimates of the Growth Rate, Cost of Capital and Risk Premium

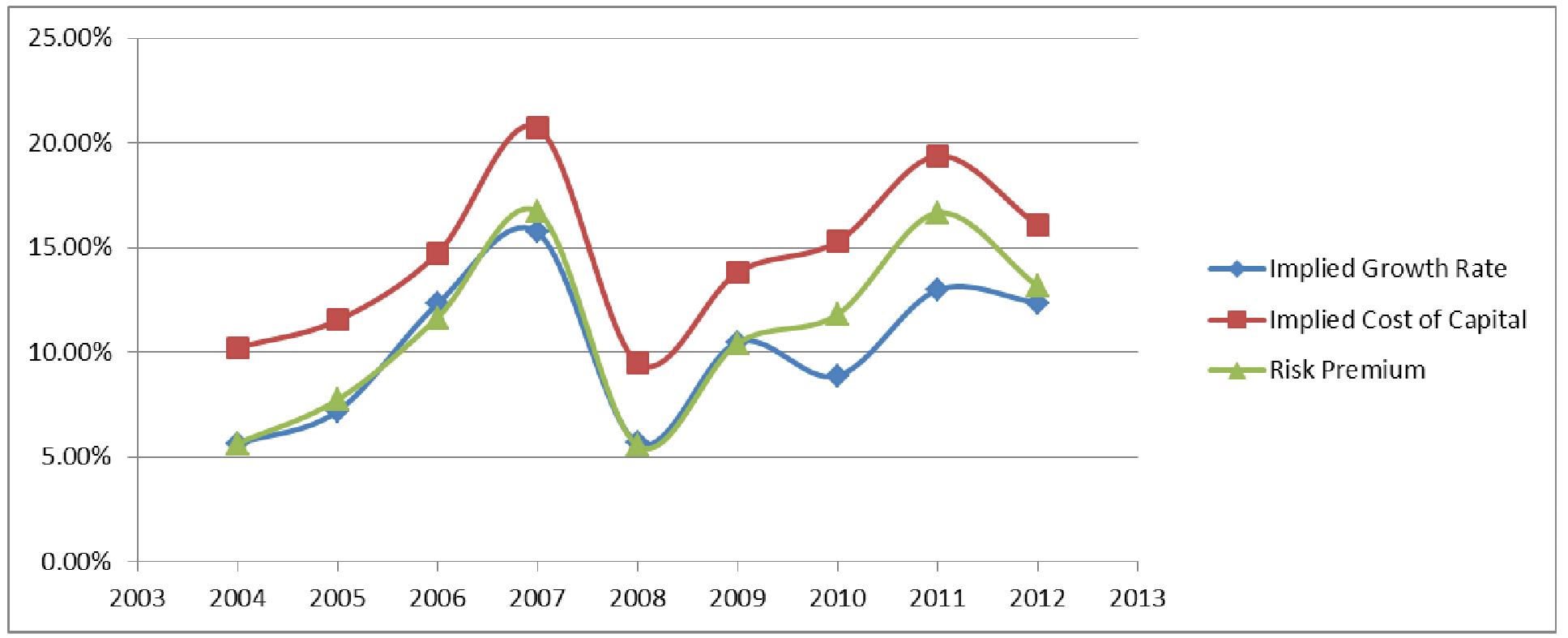

This figure shows the trends of the implied growth rate, cost of capital and risk premium over 2004-2012 based on the extended model. The risk premium is equal to the implied cost of capital and the yield on the Chinese 10-year Treasury notes. Growth rate is the expected equilibrium growth rate implied in the analysts' forecasted earnings. 
Figure 2: A Comparison of the Implied Growth Rate, Actual GDP Growth Rate and Forward One Year Actual CPI Inflation Rate

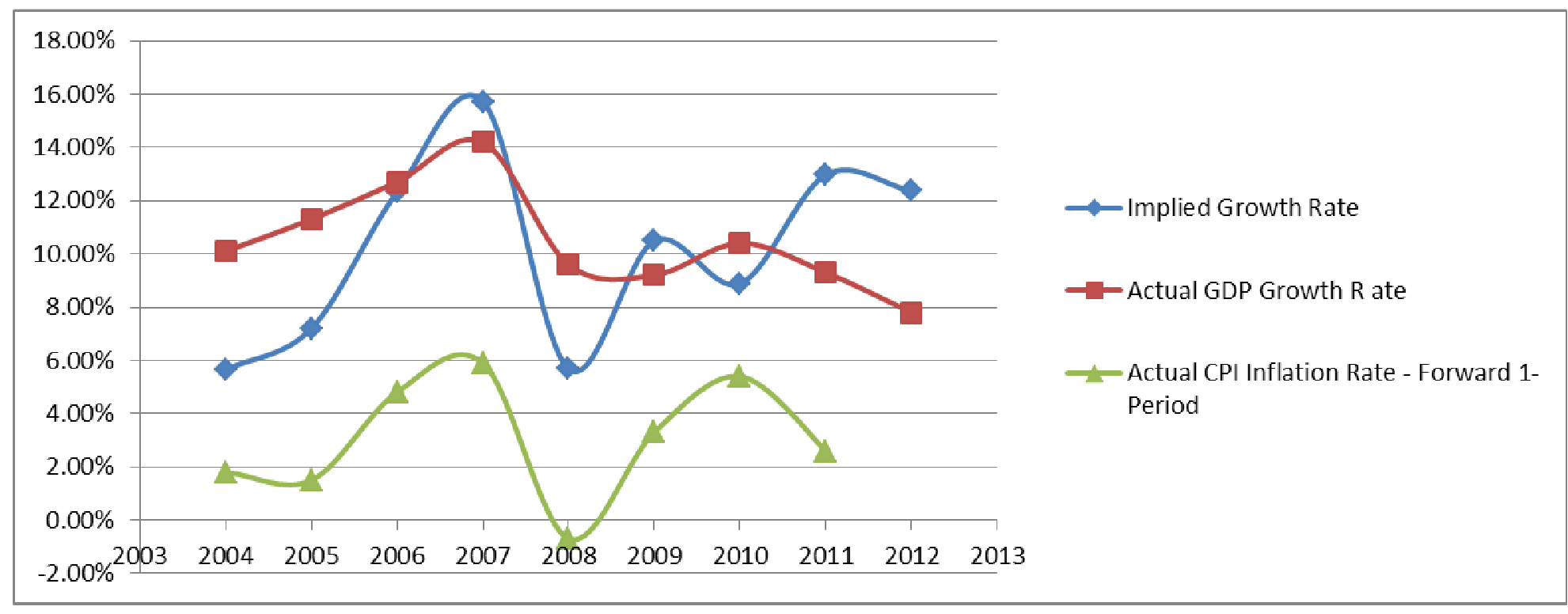

Figure 2 compares our estimates of the implied growth rate based on an extended model with actual GDP growth rate and forward one year actual CPI inflation rate. The actual GDP growth rates are $10.10 \%, 11.30 \%, 12.70 \%, 14.20 \%, 9.60 \%, 9.20 \%, 10.40 \%, 9.30 \%$, and $7.80 \%$ respectively over $2004-2012$. The actual CPI inflation rates are $3.90 \%, 1.80 \%, 1.50 \%, 4.80 \%, 5.90 \%,-0.70 \%, 3.30 \%, 5.40 \%$, and $2.60 \%$ respectively over $2004-2012$. 
Table 1: Sample Descriptive Statistics

Panel A: Sample Statistics

\begin{tabular}{lccccccccc}
\hline & feps & $\mathrm{p}$ & $\mathrm{bps}$ & $\mathrm{eps}$ & $\mathrm{dps}$ & $\mathrm{p} / \mathrm{b}$ & $\mathrm{d} / \mathrm{p}$ & roe & $\mathrm{mktcap}$ \\
\hline $\mathrm{N}$ & 7213 & 13457 & 13457 & 13457 & 13457 & 13457 & 13457 & 13457 & 13457 \\
mean & 0.71 & 12.52 & 3.79 & 0.26 & 0.07 & 3.65 & 0.01 & 0.07 & 964796 \\
$\mathrm{sd}$ & 0.57 & 12.27 & 2.46 & 0.43 & 0.19 & 2.85 & 0.03 & 0.12 & 5852437 \\
$\mathrm{p} 25$ & 0.35 & 5.29 & 2.16 & 0.04 & 0.00 & 1.84 & 0.00 & 0.02 & 149760 \\
median & 0.58 & 8.79 & 3.21 & 0.20 & 0.02 & 2.76 & 0.00 & 0.06 & 292116 \\
p75 & 0.90 & 15.04 & 4.69 & 0.43 & 0.10 & 4.46 & 0.01 & 0.12 & 594655 \\
\hline
\end{tabular}

Panel B: Sample Statistics by year

\begin{tabular}{lccccccccc}
\hline & feps & $\mathrm{p}$ & $\mathrm{bps}$ & $\mathrm{eps}$ & $\mathrm{dps}$ & $\mathrm{p} / \mathrm{b}$ & $\mathrm{d} / \mathrm{p}$ & roe & $\mathrm{mktcap}$ \\
\hline 2004 mean & 0.40 & 6.26 & 2.93 & 0.15 & 0.09 & 2.47 & 0.01 & 0.04 & 76588 \\
2004 median & 0.35 & 5.30 & 2.79 & 0.13 & 0.05 & 2.07 & 0.00 & 0.05 & 42447 \\
2005 mean & 0.42 & 5.05 & 2.81 & 0.12 & 0.08 & 2.01 & 0.01 & 0.03 & 118450 \\
2005 median & 0.37 & 4.13 & 2.67 & 0.11 & 0.01 & 1.68 & 0.00 & 0.04 & 50133 \\
2006 mean & 0.46 & 7.78 & 2.83 & 0.17 & 0.07 & 2.92 & 0.01 & 0.05 & 837588 \\
2006 median & 0.39 & 5.65 & 2.65 & 0.13 & 0.01 & 2.30 & 0.00 & 0.05 & 261290 \\
2007 mean & 0.84 & 20.29 & 3.39 & 0.27 & 0.07 & 6.56 & 0.00 & 0.08 & 1498437 \\
2007 median & 0.69 & 15.24 & 3.03 & 0.20 & 0.01 & 5.55 & 0.00 & 0.08 & 365324 \\
2008 mean & 0.66 & 7.38 & 3.12 & 0.20 & 0.07 & 2.69 & 0.00 & 0.05 & 1043939 \\
2008 median & 0.55 & 5.32 & 2.79 & 0.14 & 0.02 & 2.10 & 0.00 & 0.05 & 274605 \\
2009 mean & 0.73 & 16.61 & 3.58 & 0.26 & 0.08 & 5.32 & 0.01 & 0.07 & 1423999 \\
2009 median & 0.62 & 12.80 & 3.09 & 0.18 & 0.03 & 4.47 & 0.00 & 0.06 & 470808 \\
2010 mean & 0.90 & 20.77 & 4.56 & 0.37 & 0.11 & 5.15 & 0.00 & 0.10 & 1345029 \\
2010 median & 0.76 & 14.87 & 3.62 & 0.30 & 0.05 & 4.23 & 0.00 & 0.09 & 476900 \\
2011 mean & 0.91 & 12.72 & 4.76 & 0.37 & -0.01 & 3.01 & 0.00 & 0.08 & 972019 \\
2011 median & 0.79 & 10.09 & 4.06 & 0.30 & 0.00 & 2.46 & 0.00 & 0.07 & 309349 \\
2012 mean & 0.78 & 11.15 & 4.49 & 0.28 & 0.10 & 2.80 & 0.01 & 0.06 & 939143
\end{tabular}


Panel C: Correlation Matrix (Pearson Bottom; Spearman Top)

\begin{tabular}{llllllllll}
\hline & feps & p & eps & bps & dps & p_b & roe & d_p & mktcap \\
feps & 1.000 & 0.735 & 0.851 & 0.636 & 0.328 & 0.357 & 0.655 & 0.120 & 0.418 \\
p & 0.748 & 1.000 & 0.589 & 0.525 & 0.214 & 0.742 & 0.427 & -0.030 & 0.395 \\
eps & 0.871 & 0.608 & 1.000 & 0.602 & 0.451 & 0.224 & 0.827 & 0.276 & 0.365 \\
bps & 0.672 & 0.619 & 0.633 & 1.000 & 0.267 & -0.136 & 0.212 & 0.099 & 0.214 \\
dps & 0.358 & 0.343 & 0.436 & 0.354 & 1.000 & 0.048 & 0.352 & 0.907 & 0.096 \\
p_b & 0.299 & 0.467 & 0.076 & -0.186 & 0.022 & 1.000 & 0.335 & -0.113 & 0.286 \\
roe & 0.572 & 0.460 & 0.788 & 0.412 & 0.334 & 0.083 & 1.000 & 0.271 & 0.345 \\
d_p & 0.054 & 0.034 & 0.158 & 0.090 & 0.747 & -0.058 & 0.161 & 1.000 & 0.009 \\
mktcap & 0.089 & 0.066 & 0.134 & 0.055 & 0.072 & 0.013 & 0.110 & 0.052 & 1.000 \\
\hline
\end{tabular}

Notes:

Panel A shows descriptive statistics for 13,457 firm-year (except forecasted earnings per share (feps) with 7,213 observations) between 2004 and 2012 . feps is the average institutional investor forecasts of earnings per share made around the corresponding reported prior-year earnings announcements. P, bps, eps, dps are respectively stock price, equity book value per share, earnings per share and dividend per share. mktcap is the market capitalization of A-shares defined by price multiplied by the number of Ashares. Earnings are net income per share before extraordinary items. p/b is the market-to-book ratio. Return on equity (roe) is net income before extraordinary items scaled by lagged book value. $\mathrm{d} / \mathrm{p}$ is dividends scaled by lagged price of equity. Firms with negative book value and in the extreme percentiles with $\mathrm{p} / \mathrm{b}$ and roe are deleted. The mean, standard deviation (stdev), median and first (Q1) and third (Q3) quartiles are reported.

Panel B shows the mean and median of variables in interest on a year-by-year basis.

Panel C shows the annual cross-sectional correlations for 9,982 firm-year observations. The upper (lower) right triangle of the matrix shows Spearman (Pearson) correlations. 
Table 2. The Coefficients for Regressing Forecasted Earnings on Price, Earnings, Book Value and Lagged Book Value and Lagged Price, Year-by-Year.

Panel A-Simple model: $\frac{f e p s_{t+1}}{b_{t}}=\delta_{1} \frac{P_{t}}{b_{t}}+\delta_{2} \frac{e_{t}}{b_{t}}+\delta_{3}+\delta_{4} \frac{b_{t-1}}{b_{t}}+\varepsilon_{t+1}$

\begin{tabular}{|c|c|c|c|c|c|c|c|c|c|}
\hline Year & 2004 & 2005 & 2006 & 2007 & 2008 & 2009 & 2010 & 2011 & 2012 \\
\hline $\mathrm{N}$ & 630 & 610 & 820 & 593 & 595 & 866 & 1009 & 1022 & 1068 \\
\hline delta1 & 0.025 & 0.023 & 0.008 & 0.015 & 0.027 & 0.018 & 0.015 & 0.018 & 0.013 \\
\hline t-stat & 8.17 & 7.15 & 4.35 & 5.42 & 7.35 & 9.31 & 7.41 & 8.49 & 9.95 \\
\hline delta2 & 0.471 & 0.503 & 0.648 & 0.748 & 0.374 & 0.555 & 0.833 & 0.830 & 0.678 \\
\hline t-stat & 6.33 & 9.07 & 7.37 & 6.51 & 5.92 & 9.13 & 14.20 & 15.32 & 15.06 \\
\hline delta3 & 0.011 & 0.013 & 0.016 & 0.059 & 0.062 & 0.026 & 0.011 & 0.039 & 0.055 \\
\hline t-stat & 1.06 & 0.84 & 1.11 & 1.79 & 4.63 & 1.73 & 0.72 & 4.29 & 5.62 \\
\hline delta4 & 0.027 & 0.027 & 0.038 & -0.009 & -0.024 & 0.026 & 0.015 & -0.005 & -0.003 \\
\hline t-stat & 2.91 & 2.06 & 3.02 & -0.31 & -1.94 & 1.71 & 1.24 & -0.88 & -0.49 \\
\hline R2-adj. & $65.19 \%$ & $71.20 \%$ & $65.62 \%$ & $54.80 \%$ & $58.99 \%$ & $62.83 \%$ & $73.23 \%$ & $83.21 \%$ & $74.98 \%$ \\
\hline
\end{tabular}

Panel -B Extended model: $\frac{\text { eeps }_{t+1}}{b_{t}}=\delta_{1}^{\prime} \frac{P_{t}}{b_{t}}+\delta_{2}^{\prime} \frac{e_{t}}{b_{t}}+\delta_{3}^{\prime}+\delta_{4}^{\prime} \frac{b_{t-1}}{b_{t}}+\delta_{5}^{\prime} \frac{P_{t-1}}{b_{t}}+\varepsilon_{t+1}^{\prime}$

\begin{tabular}{lrrrrrrrrr}
\hline Year & \multicolumn{1}{c}{2004} & \multicolumn{1}{c}{2005} & \multicolumn{1}{c}{2006} & \multicolumn{1}{c}{2007} & \multicolumn{1}{c}{2008} & \multicolumn{2}{c}{2009} & 2010 & \multicolumn{2}{l}{2011} & 2012 \\
\hline $\mathrm{N}$ & 585 & 601 & 767 & 538 & 563 & 804 & 834 & 903 & 1010 \\
delta1 & 0.021 & 0.023 & 0.007 & 0.013 & 0.021 & 0.023 & 0.014 & 0.016 & 0.009 \\
t-stat & 4.53 & 5.26 & 2.96 & 5.36 & 3.47 & 7.66 & 4.19 & 4.30 & 4.58 \\
delta2 & 0.476 & 0.501 & 0.595 & 0.825 & 0.343 & 0.542 & 0.810 & 0.818 & 0.656 \\
t-stat & 6.08 & 9.01 & 7.26 & 9.32 & 5.68 & 8.59 & 12.87 & 14.61 & 14.59 \\
delta3 & 0.017 & 0.014 & 0.051 & 0.066 & 0.081 & 0.039 & 0.024 & 0.049 & 0.080 \\
t-stat & 1.31 & 0.91 & 3.05 & 2.00 & 4.84 & 1.69 & 1.05 & 4.59 & 7.79
\end{tabular}




\begin{tabular}{lrrrrrrrrr} 
delta4 & 0.015 & 0.026 & 0.008 & -0.024 & -0.045 & 0.015 & -0.001 & -0.014 & -0.031 \\
t-stat & 0.93 & 1.82 & 0.62 & -0.66 & -2.85 & 0.64 & -0.05 & -1.23 & -3.45 \\
delta5 & 0.004 & 0.000 & 0.005 & 0.001 & 0.005 & -0.006 & 0.002 & 0.001 & 0.007 \\
t-stat & 1.31 & 0.08 & 1.24 & 0.36 & 1.96 & -1.66 & 0.83 & 0.50 & 2.63 \\
\hline R2-adj. & $65.48 \%$ & $71.17 \%$ & $64.95 \%$ & $61.71 \%$ & $60.25 \%$ & $64.21 \%$ & $72.84 \%$ & $83.18 \%$ & $76.18 \%$ \\
\hline
\end{tabular}

Notes:

Table 2 reports the coefficients for the 9 value-weighted regressions based on annual estimates between 2004-2012, together with descriptive statistics of their t-values. feps $_{t+1}$ is the average institutional investor forecasts of earnings per share made around the corresponding reported prior-year earnings announcements; $P_{t}$ and $P_{\mathrm{t}-1}$ are the contemporary equity price and lagged equity price respectively; $b_{t}$ and $b_{t-1}$ are the contemporary book value of equity and lagged book value of equity per share respectively; and $e_{t}$ is net income (before extraordinary items) per share. $\mathrm{N}$ is the annual numbers of observations. 
Table 3. Implied Growth Rate, Cost of Capital and Risk Premium, Year-by-Year

\begin{tabular}{|c|c|c|c|c|c|c|c|c|c|c|c|c|}
\hline \multirow[b]{3}{*}{ Year } & \multicolumn{6}{|c|}{$\underline{\text { Panel A: Simple Model }}$} & \multicolumn{6}{|c|}{$\underline{\text { Panel B: Extended Model }}$} \\
\hline & \multirow[b]{2}{*}{ Sample Size } & \multicolumn{2}{|c|}{ Growth } & \multicolumn{2}{|c|}{ Cost of Capital } & \multirow[t]{2}{*}{$\mathrm{RP}$} & \multirow[b]{2}{*}{ Sample Size } & \multicolumn{2}{|c|}{ Growth } & \multicolumn{2}{|c|}{ Cost of Capital } & \multirow{2}{*}{$\begin{array}{l}\mathrm{RP} \\
\end{array}$} \\
\hline & & $\%$ & t-stat & $\%$ & t-stat & & & $\%$ & t-stat & $\%$ & t-stat & \\
\hline 2004 & 630 & $6.53 \%$ & 7.36 & $10.93 \%$ & 15.78 & $6.36 \%$ & 585 & $5.65 \%$ & 6.26 & $10.23 \%$ & 14.68 & $5.66 \%$ \\
\hline 2005 & 610 & $7.24 \%$ & 6.31 & $11.56 \%$ & 15.85 & $7.77 \%$ & 601 & $7.20 \%$ & 5.81 & $11.53 \%$ & 14.73 & $7.74 \%$ \\
\hline 2006 & 820 & $11.74 \%$ & 6.12 & $13.57 \%$ & 7.87 & $10.51 \%$ & 767 & $12.32 \%$ & 6.42 & $14.72 \%$ & 8.03 & $11.66 \%$ \\
\hline 2007 & 593 & $14.71 \%$ & 6.11 & $19.03 \%$ & 8.30 & $15.01 \%$ & 538 & $15.72 \%$ & 4.69 & $20.73 \%$ & 6.84 & $16.71 \%$ \\
\hline 2008 & 595 & $6.06 \%$ & 3.83 & $10.23 \%$ & 8.38 & $6.28 \%$ & 563 & $5.68 \%$ & 3.73 & $9.51 \%$ & 7.95 & $5.56 \%$ \\
\hline 2009 & 866 & $10.15 \%$ & 7.74 & $13.78 \%$ & 12.65 & $10.40 \%$ & 804 & $10.49 \%$ & 8.43 & $13.81 \%$ & 13.29 & $10.43 \%$ \\
\hline 2010 & 1009 & $10.00 \%$ & 4.66 & $16.26 \%$ & 9.74 & $12.79 \%$ & 834 & $8.88 \%$ & 3.60 & $15.29 \%$ & 8.85 & $11.82 \%$ \\
\hline 2011 & 1022 & $12.98 \%$ & 6.84 & $19.59 \%$ & 12.22 & $16.87 \%$ & 903 & $12.97 \%$ & 6.50 & $19.37 \%$ & 11.77 & $16.65 \%$ \\
\hline 2012 & 1068 & $13.05 \%$ & 15.80 & $16.42 \%$ & 26.56 & $13.51 \%$ & 1010 & $12.37 \%$ & 13.07 & $16.07 \%$ & 24.01 & $13.16 \%$ \\
\hline Mean & 801 & $10.27 \%$ & 7.20 & $14.60 \%$ & 13.04 & $11.05 \%$ & 734 & $10.14 \%$ & 6.50 & $14.58 \%$ & 12.24 & $11.04 \%$ \\
\hline Stdev & 200 & $3.12 \%$ & 3.45 & $3.43 \%$ & 5.92 & $3.79 \%$ & 169 & $3.52 \%$ & 2.89 & $3.84 \%$ & 5.35 & $4.18 \%$ \\
\hline Minimum & 593 & $6.06 \%$ & 3.83 & $10.23 \%$ & 7.87 & $6.28 \%$ & 538 & $5.65 \%$ & 3.60 & $9.51 \%$ & 6.84 & $5.56 \%$ \\
\hline Lower Quartile & 610 & $7.24 \%$ & 6.11 & $11.56 \%$ & 8.38 & $7.77 \%$ & 585 & $7.20 \%$ & 4.69 & $11.53 \%$ & 8.03 & $7.74 \%$ \\
\hline Median & 820 & $10.15 \%$ & 6.31 & $13.78 \%$ & 12.22 & $10.51 \%$ & 767 & $10.49 \%$ & 6.26 & $14.72 \%$ & 11.77 & $11.66 \%$ \\
\hline Upper Quartile & 1009 & $12.98 \%$ & 7.36 & $16.42 \%$ & 15.78 & $13.51 \%$ & 834 & $12.37 \%$ & 6.50 & $16.07 \%$ & 14.68 & $13.16 \%$ \\
\hline Maximum & 1068 & $14.71 \%$ & 15.80 & $19.59 \%$ & 26.56 & $16.87 \%$ & 1010 & $15.72 \%$ & 13.07 & $20.73 \%$ & 24.01 & $16.71 \%$ \\
\hline
\end{tabular}

Notes:

Table 3 reports the implied growth rates, cost of capital and risk premia computed on an annual basis.

Panel A reports results from using the simple value-weighted regression model:

$\frac{\text { eeps }_{t+1}}{b_{t}}=\delta_{1} \frac{P_{t}}{b_{t}}+\delta_{2} \frac{e_{t}}{b_{t}}+\delta_{3}+\delta_{4} \frac{b_{t-1}}{b_{t}}+\varepsilon_{t+1}$, and $g=\frac{\left(1+\delta_{2}+\delta_{3}\right)+\sqrt{\left(1+\delta_{2}+\delta_{3}\right)^{2}-4\left(\delta_{2}-\delta_{4}\right)}}{2}-1, R-1=(1+g)\left(1+\frac{\delta_{1}}{1+g-\delta_{2}}\right)-1$.

Panel B reports results from using the extended value-weighted regression model:

$\frac{f e p s_{t+1}}{b_{t}}=\delta_{1}^{\prime} \frac{P_{t}}{b_{t}}+\delta_{2}^{\prime} \frac{e_{t}}{b_{t}}+\delta_{3}^{\prime}+\delta_{4}^{\prime} \frac{b_{t-1}}{b_{t}}+\delta_{5}^{\prime} \frac{P_{t-1}}{b_{t}}+\varepsilon_{t+1}^{\prime}$, and $g=\frac{1+\delta_{2}^{\prime}+\delta_{3}^{\prime}-\delta_{5}^{\prime}+\sqrt{\left(1+\delta_{2}^{\prime}+\delta_{3}^{\prime}-\delta_{5}^{\prime}\right)^{2}-4\left(\delta_{2}^{\prime}-\delta_{4}^{\prime}-\delta_{5}^{\prime}\right)}}{2}-1, R-1=(1+g)\left(1+\frac{\delta_{1}^{\prime}+\delta_{5}^{\prime}}{1+g-\delta_{2}^{\prime}}\right)-1$.

The risk premium (RP) is calculated relative to the yield on the Chinese 10-year Treasury notes. feps $s_{t+1}$ is the average institutional investor forecasts of earnings per share made around the reported prior-year earnings announcements; $P_{t}$ and $P_{\mathrm{t}-1}$ are the contemporary equity price and lagged equity price respectively; $b_{t}$ and $b_{t-1}$ are the contemporary book value of equity and lagged book value of equity per share respectively; and $e_{t}$ is the net income (before extraordinary items) per share. 
Table 4. The Descriptive Statistics for Regressing Forecasted Earnings on Price, Earnings, Book Value and Lagged Book Value and Price, Industry-by-Industry

Panel A: Simple Model $\frac{\text { feps }_{t+1}}{b_{t}}=\delta_{1} \frac{P_{t}}{b_{t}}+\delta_{2} \frac{e_{t}}{b_{t}}+\delta_{3}+\delta_{4} \frac{b_{t-1}}{b_{t}}+\varepsilon_{t+1}$

\begin{tabular}{|c|c|c|c|c|c|c|c|c|c|c|c|c|c|}
\hline Industry & Agriculture & Mining & Manufacturing & Utilities & Construction & Transportation & Computers & $\begin{array}{l}\text { Wsale } \\
\text { Retail }\end{array}$ & $\begin{array}{l}\text { Banking } \\
\text { Insur }\end{array}$ & $\begin{array}{l}\text { Real } \\
\text { Estate }\end{array}$ & Services & Entertainment & others \\
\hline $\mathrm{N}$ & 122 & 260 & 4119 & 247 & 144 & 356 & 515 & 443 & 198 & 356 & 228 & 96 & 129 \\
\hline delta1 & 0.018 & 0.013 & 0.016 & 0.017 & 0.010 & 0.020 & 0.017 & 0.013 & 0.009 & 0.025 & 0.017 & 0.011 & 0.018 \\
\hline t-stat & 8.92 & 4.22 & 14.23 & 3.26 & 3.58 & 3.54 & 4.78 & 6.81 & 3.97 & 6.39 & 8.14 & 5.29 & 2.13 \\
\hline delta2 & 0.570 & 0.561 & 0.488 & 0.437 & 0.896 & 0.425 & 0.261 & 0.709 & 0.393 & 0.330 & 0.406 & 0.599 & 0.814 \\
\hline t-stat & 8.29 & 4.21 & 10.22 & 2.85 & 5.97 & 4.46 & 3.62 & 11.75 & 3.92 & 4.16 & 2.65 & 3.10 & 5.89 \\
\hline delta3 & -0.001 & 0.059 & 0.038 & 0.020 & 0.035 & 0.043 & 0.031 & 0.039 & 0.096 & 0.061 & 0.023 & 0.018 & 0.062 \\
\hline t-stat & -0.18 & 3.63 & 6.58 & 0.76 & 3.79 & 2.67 & 2.42 & 4.90 & 3.23 & 1.98 & 4.85 & 1.48 & 2.15 \\
\hline delta4 & 0.029 & 0.010 & 0.014 & 0.036 & 0.007 & 0.000 & 0.024 & -0.001 & -0.003 & 0.015 & 0.015 & 0.018 & -0.022 \\
\hline t-stat & 4.84 & 0.82 & 2.95 & 2.26 & 6.55 & 0.00 & 3.57 & -0.08 & -0.08 & 0.67 & 1.70 & 2.05 & -1.36 \\
\hline R2-adj. & $74.75 \%$ & $62.43 \%$ & $62.96 \%$ & $40.44 \%$ & $80.92 \%$ & $55.76 \%$ & $52.15 \%$ & $69.56 \%$ & $41.81 \%$ & $40.06 \%$ & $50.69 \%$ & $58.32 \%$ & $51.81 \%$ \\
\hline
\end{tabular}

Panel B: Extended Model $\frac{\text { epps }_{t+1}}{b_{t}}=\delta_{1}^{\prime} \frac{P_{t}}{b_{t}}+\delta_{2}^{\prime} \frac{e_{t}}{b_{t}}+\delta_{3}^{\prime}+\delta_{4}^{\prime} \frac{b_{t-1}}{b_{t}}+\delta_{5}^{\prime} \frac{P_{t-1}}{b_{t}}+\varepsilon_{t+1}^{\prime}$

\begin{tabular}{|c|c|c|c|c|c|c|c|c|c|c|c|c|c|}
\hline Industry & Agriculture & Mining & Manufacturing & Utilities & Construction & Transportation & Computers & $\begin{array}{l}\text { Wsale } \\
\text { Retail }\end{array}$ & $\begin{array}{l}\text { Banking } \\
\text { Insur }\end{array}$ & $\begin{array}{l}\text { Real } \\
\text { Estate }\end{array}$ & Services & Entertainment & others \\
\hline $\mathrm{N}$ & 122 & 260 & 4119 & 247 & 144 & 356 & 515 & 443 & 198 & 356 & 228 & 96 & 129 \\
\hline delta1 & 0.016 & 0.013 & 0.014 & 0.013 & 0.006 & 0.021 & 0.015 & 0.011 & 0.008 & 0.020 & 0.017 & 0.011 & 0.015 \\
\hline t-stat & 5.86 & 3.65 & 11.56 & 2.24 & 2.35 & 4.62 & 4.02 & 7.12 & 2.91 & 4.93 & 5.90 & 3.59 & 1.47 \\
\hline delta2 & 0.512 & 0.555 & 0.457 & 0.417 & 0.785 & 0.428 & 0.211 & 0.645 & 0.369 & 0.291 & 0.387 & 0.572 & 0.774 \\
\hline t-stat & 7.27 & 4.08 & 9.49 & 3.02 & 5.92 & 4.44 & 3.54 & 9.23 & 3.98 & 4.08 & 2.55 & 3.16 & 6.79 \\
\hline delta3 & 0.010 & 0.062 & 0.058 & 0.029 & 0.077 & 0.037 & 0.045 & 0.059 & 0.115 & 0.077 & 0.032 & 0.022 & 0.075 \\
\hline t-stat & 0.65 & 3.41 & 9.17 & 1.22 & 6.02 & 2.09 & 3.31 & 7.84 & 3.37 & 2.10 & 4.72 & 1.60 & 2.30 \\
\hline delta4 & 0.011 & 0.009 & -0.010 & 0.014 & -0.036 & 0.008 & -0.002 & -0.025 & -0.025 & -0.020 & 0.001 & 0.011 & -0.049 \\
\hline t-stat & 0.86 & 0.65 & -1.95 & 0.96 & -2.80 & 0.41 & -0.27 & -7.81 & -0.66 & -0.70 & 0.07 & 0.66 & -2.59 \\
\hline delta5 & 0.004 & -0.001 & 0.004 & 0.009 & 0.009 & -0.002 & 0.005 & 0.005 & 0.003 & 0.012 & 0.003 & 0.002 & 0.008 \\
\hline t-stat & 1.77 & -0.40 & 4.67 & 23.34 & 5.03 & -0.46 & 2.44 & 3.37 & 1.36 & 3.00 & 0.89 & 0.57 & 2.09 \\
\hline R2-adj. & $76.09 \%$ & $61.69 \%$ & $64.24 \%$ & $42.81 \%$ & $83.87 \%$ & $59.42 \%$ & $56.52 \%$ & $71.21 \%$ & $42.11 \%$ & $43.78 \%$ & $51.53 \%$ & $57.87 \%$ & $53.24 \%$ \\
\hline
\end{tabular}

Notes: 
Table 4 reports the descriptive statistics for the 13 regression coefficients of $\delta_{i}$ and $\delta_{i}^{\prime}$ based on the 13 industry groups over the period 2004-2012, together with descriptive statistics of their t-values. Two-way cluster-robust standard errors are used to correct for both cross-sectional and time-series dependence. Industry classification follows that of the China Securities Regulatory Commission. feps $s_{t+1}$ is the average institutional investor forecasts of earnings per share made around the reported prior-year earning announcements; $P_{t}$ and $P_{\mathrm{t}-1}$ are the contemporary equity price and lagged equity price respectively; $b_{t}$ and $b_{t-1}$ are the contemporary book value of equity and lagged book value of equity per share respectively; and $e_{t}$ is the net income before extraordinary items per share. $\mathrm{N}$ is the annual numbers of observations. 
Table 5. Implied Growth Rate, Cost of Capital and Risk Premia, Industry-by-Industry

\begin{tabular}{|c|c|c|c|c|c|c|c|c|c|c|c|}
\hline \multirow[b]{3}{*}{ Industry } & \multirow[b]{3}{*}{$\begin{array}{l}\text { Sample } \\
\text { Size }\end{array}$} & \multicolumn{5}{|c|}{ Panel A: Simple Model } & \multicolumn{5}{|c|}{ Panel B: Extended Model } \\
\hline & & \multicolumn{2}{|c|}{ Growth } & \multicolumn{2}{|c|}{ Cost of Capital } & \multirow[t]{2}{*}{$\mathrm{RP}$} & \multicolumn{2}{|c|}{ Growth } & \multicolumn{2}{|c|}{ Cost of Capital } & \multirow[t]{2}{*}{$\mathrm{RP}$} \\
\hline & & $\%$ & t-stat & $\%$ & t-stat & & $\%$ & t-stat & $\%$ & t-stat & \\
\hline Agriculture & 122 & $5.63 \%$ & 3.64 & $9.48 \%$ & 8.32 & $6.01 \%$ & $3.98 \%$ & 3.57 & $8.01 \%$ & 7.95 & $4.54 \%$ \\
\hline Mining & 260 & $13.49 \%$ & 6.22 & $15.98 \%$ & 17.44 & $12.53 \%$ & $13.77 \%$ & 6.43 & $16.20 \%$ & 16.76 & $12.74 \%$ \\
\hline Manufacturing & 4119 & $9.13 \%$ & 12.89 & $12.10 \%$ & 29.65 & $8.67 \%$ & $8.28 \%$ & 11.22 & $11.52 \%$ & 28.45 & $8.09 \%$ \\
\hline Utilities & 247 & $8.86 \%$ & 4.10 & $11.71 \%$ & 8.55 & $8.18 \%$ & $6.78 \%$ & 3.17 & $10.42 \%$ & 7.41 & $6.89 \%$ \\
\hline Construction & 144 & $17.46 \%$ & 4.14 & $21.81 \%$ & 4.78 & $18.40 \%$ & $14.15 \%$ & 4.04 & $18.84 \%$ & 5.02 & $15.43 \%$ \\
\hline Transportation & 356 & $7.09 \%$ & 3.43 & $10.34 \%$ & 10.15 & $6.84 \%$ & $7.34 \%$ & 3.04 & $10.50 \%$ & 8.37 & $7.00 \%$ \\
\hline Computers & 515 & $7.06 \%$ & 3.79 & $9.28 \%$ & 11.37 & $5.92 \%$ & $5.29 \%$ & 3.51 & $7.85 \%$ & 10.17 & $4.49 \%$ \\
\hline Wsale Retail & 443 & $10.82 \%$ & 6.46 & $14.48 \%$ & 10.97 & $10.98 \%$ & $8.81 \%$ & 4.26 & $12.81 \%$ & 9.01 & $9.31 \%$ \\
\hline Banking Insur & 198 & $14.28 \%$ & 15.19 & $15.68 \%$ & 19.14 & $12.25 \%$ & $13.79 \%$ & 12.75 & $15.41 \%$ & 14.39 & $11.98 \%$ \\
\hline Real Estate & 356 & $10.66 \%$ & 4.11 & $14.24 \%$ & 14.18 & $10.73 \%$ & $7.85 \%$ & 3.18 & $12.34 \%$ & 12.39 & $8.84 \%$ \\
\hline Services & 228 & $6.11 \%$ & 5.45 & $8.92 \%$ & 6.21 & $5.49 \%$ & $5.19 \%$ & 4.14 & $8.23 \%$ & 4.92 & $4.80 \%$ \\
\hline Entertainment & 96 & $7.89 \%$ & 4.26 & $10.42 \%$ & 6.49 & $7.03 \%$ & $6.80 \%$ & 3.16 & $9.54 \%$ & 6.02 & $6.14 \%$ \\
\hline others & 129 & $14.55 \%$ & 1.55 & $20.74 \%$ & 2.91 & $17.19 \%$ & $9.90 \%$ & 1.42 & $17.65 \%$ & 2.74 & $14.10 \%$ \\
\hline Mean & 555 & $10.23 \%$ & 5.79 & $13.47 \%$ & 11.55 & $10.02 \%$ & $8.61 \%$ & 4.91 & $12.26 \%$ & 10.28 & $8.80 \%$ \\
\hline Stdev & 1079 & $3.71 \%$ & 3.90 & $4.22 \%$ & 7.21 & $4.20 \%$ & $3.40 \%$ & 3.34 & $3.72 \%$ & 6.73 & $3.71 \%$ \\
\hline Minimum & 96 & $5.63 \%$ & 1.55 & $8.92 \%$ & 2.91 & $5.49 \%$ & $3.98 \%$ & 1.42 & $7.85 \%$ & 2.74 & $4.49 \%$ \\
\hline $\begin{array}{l}\text { Lower } \\
\text { Quartile }\end{array}$ & 144 & $7.09 \%$ & 3.79 & $10.34 \%$ & 6.49 & $6.84 \%$ & $6.78 \%$ & 3.17 & $9.54 \%$ & 6.02 & $6.14 \%$ \\
\hline Median & 247 & $9.13 \%$ & 4.14 & $12.10 \%$ & 10.15 & $8.67 \%$ & $7.85 \%$ & 3.57 & $11.52 \%$ & 8.37 & $8.09 \%$ \\
\hline $\begin{array}{l}\text { Upper } \\
\text { Quartile }\end{array}$ & 356 & $13.49 \%$ & 6.22 & $15.68 \%$ & 14.18 & $12.25 \%$ & $9.90 \%$ & 4.26 & $15.41 \%$ & 12.39 & $11.98 \%$ \\
\hline Maximum & 4119 & $17.46 \%$ & 15.19 & $21.81 \%$ & 29.65 & $18.40 \%$ & $14.15 \%$ & 12.75 & $18.84 \%$ & 28.45 & $15.43 \%$ \\
\hline
\end{tabular}

Notes:

Table 5 reports the implied growth rate, cost of capital and risk premia computed on an industry basis. Industry classification follows that of the China Securities Regulatory

Commission.

Panel A reports results from using the simple regression model: 


$$
\frac{\text { feps }_{t+1}}{b_{t}}=\delta_{1} \frac{P_{t}}{b_{t}}+\delta_{2} \frac{e_{t}}{b_{t}}+\delta_{3}+\delta_{4} \frac{b_{t-1}}{b_{t}}+\varepsilon_{t+1}, \text { and } g=\frac{\left(1+\delta_{2}+\delta_{3}\right)+\sqrt{\left(1+\delta_{2}+\delta_{3}\right)^{2}-4\left(\delta_{2}-\delta_{4}\right)}}{2}-1, R-1=(1+g)\left(1+\frac{\delta_{1}}{1+g-\delta_{2}}\right)-1 \text {. }
$$

Panel B reports results from using the extended regression model:

$$
\frac{f e p s_{t+1}}{b_{t}}=\delta_{1}^{\prime} \frac{P_{t}}{b_{t}}+\delta_{2}^{\prime} \frac{e_{t}}{b_{t}}+\delta_{3}^{\prime}+\delta_{4}^{\prime} \frac{b_{t-1}}{b_{t}}+\delta_{5}^{\prime} \frac{P_{t-1}}{b_{t}}+\varepsilon_{t+1}^{\prime}, \text { and } g=\frac{1+\delta_{2}^{\prime}+\delta_{3}^{\prime}-\delta_{5}^{\prime}+\sqrt{\left(1+\delta_{2}^{\prime}+\delta_{3}^{\prime}-\delta_{5}^{\prime}\right)^{2}-4\left(\delta_{2}^{\prime}-\delta_{4}^{\prime}-\delta_{5}^{\prime}\right)}}{2}-1, R-1=(1+g)\left(1+\frac{\delta_{1}^{\prime}+\delta_{5}^{\prime}}{1+g-\delta_{2}^{\prime}}\right)-1
$$

The risk premium (RP) is calculated relative to the yield on the Chinese 10-year Treasury notes. feps $s_{t+1}$ is the average institutional investor forecasts of earnings per share made around the corresponding reported prior-year earnings announcements; $P_{t}$ and $P_{\mathrm{t}-1}$ are the contemporary equity price and lagged equity price respectively; $b_{t}$ and $b_{t-1}$ are the contemporary book value of equity and lagged book value of equity per share respectively; and $e_{t}$ is the net income before extraordinary items per share. $\mathrm{N}$ is the annual numbers of observations. Two-way cluster-robust standard errors are used to correct for both cross-sectional and time-series dependence. 
Table 6. Implied Real Growth Rate and Real Cost of Capital, Year-by-Year

Panel A: Simple Model

\begin{tabular}{|c|c|c|c|c|c|c|}
\hline \multirow[b]{2}{*}{ Year } & \multirow[b]{2}{*}{$\begin{array}{l}\text { Sample } \\
\text { Size }\end{array}$} & \multirow[b]{2}{*}{ Inflation \% } & \multicolumn{2}{|c|}{ Panel A: Simple Model } & \multicolumn{2}{|c|}{ Panel B: Extended Model } \\
\hline & & & $\begin{array}{r}\text { Real Growth } \\
\text { Rate } \%\end{array}$ & $\begin{array}{r}\text { Real Cost of } \\
\text { Capital \% } \\
\end{array}$ & $\begin{array}{r}\text { Real Growth } \\
\text { Rate } \% \\
\end{array}$ & $\begin{array}{r}\text { Real Cost of } \\
\text { Capital \% } \\
\end{array}$ \\
\hline 2004 & 630 & 1.07 & 5.39 & 9.76 & 4.50 & 9.05 \\
\hline 2005 & 610 & 1.35 & 5.93 & 10.07 & 5.85 & 10.02 \\
\hline 2006 & 820 & 1.51 & 10.05 & 11.85 & 10.59 & 12.95 \\
\hline 2007 & 593 & 2.63 & 14.28 & 17.17 & 14.73 & 17.96 \\
\hline 2008 & 595 & 3.57 & 2.37 & 6.39 & 2.00 & 5.69 \\
\hline 2009 & 866 & 2.63 & 7.27 & 10.74 & 7.60 & 10.78 \\
\hline 2010 & 1009 & 2.93 & 6.87 & 12.93 & 5.79 & 11.98 \\
\hline 2011 & 1022 & 3.71 & 8.93 & 15.31 & 8.93 & 15.10 \\
\hline 2012 & 1068 & 3.27 & 9.47 & 12.73 & 8.81 & 12.39 \\
\hline Mean & 801 & 2.52 & 7.84 & 11.88 & 7.64 & 11.77 \\
\hline Stdev & 200 & 0.99 & 3.37 & 3.18 & 3.71 & 3.53 \\
\hline Minimum & 593 & 1.07 & 2.37 & 6.39 & 2.00 & 5.69 \\
\hline Lower Quartile & 610 & 1.51 & 5.93 & 10.07 & 5.79 & 10.02 \\
\hline Median & 820 & 2.63 & 7.27 & 11.85 & 7.60 & 11.98 \\
\hline Upper Quartile & 1009 & 3.27 & 9.47 & 12.93 & 8.93 & 12.95 \\
\hline Maximum & 1068 & 3.71 & 14.28 & 17.17 & 14.73 & 17.96 \\
\hline
\end{tabular}

Notes:

Table 6 reports the implied real growth rates and real cost of capital computed on annual basis.

Panel A reports results from using the simple value-weighted regression model:

$\frac{f e p s_{t+1}}{b_{t}}=\delta_{1} \frac{P_{t}}{b_{t}}+\delta_{2} \frac{e_{t}}{b_{t}}+\delta_{3}+\delta_{4} \frac{b_{t-1}}{b_{t}}+\varepsilon_{t+1}$, and $g=\frac{\left(1+\delta_{2}+\delta_{3}\right)+\sqrt{\left(1+\delta_{2}+\delta_{3}\right)^{2}-4\left(\delta_{2}-\delta_{4}\right)}}{2}-1, R-1=(1+g)\left(1+\frac{\delta_{1}}{1+g-\delta_{2}}\right)-1$.

Panel B reports results from using the extended value-weighted regression model:

$\frac{f e p s_{t+1}}{b_{t}}=\delta_{1}^{\prime} \frac{P_{t}}{b_{t}}+\delta_{2}^{\prime} \frac{e_{t}}{b_{t}}+\delta_{3}^{\prime}+\delta_{4}^{\prime} \frac{b_{t-1}}{b_{t}}+\delta_{5}^{\prime} \frac{P_{t-1}}{b_{t}}+\varepsilon_{t+1}^{\prime}$, and $g=\frac{1+\delta_{2}^{\prime}+\delta_{3}^{\prime}-\delta_{5}^{\prime}+\sqrt{\left(1+\delta_{2}^{\prime}+\delta_{3}^{\prime}-\delta_{5}^{\prime}\right)^{2}-4\left(\delta_{2}^{\prime}-\delta_{4}^{\prime}-\delta_{5}^{\prime}\right)}}{2}-1, R-1=(1+g)\left(1+\frac{\delta_{1}^{\prime}+\delta_{5}^{\prime}}{1+g-\delta_{2}^{\prime}}\right)-1$.

feps $_{t+1}$ is the average institutional investor forecasts of earnings per share made around the corresponding reported prior-year earnings announcements; $P_{t}$ and $P_{\mathrm{t}-1}$ are the contemporary equity price and lagged equity price respectively; $b_{t}$ and $b_{t-1}$ are the contemporary book value of equity and lagged book value of equity per share respectively; and $e_{t}$ is the net income before extraordinary items per share. The expected inflation rate is estimated as the geometric mean of the prior 5-year actual CPI inflation rate. 
Table 7. Implied Real Growth Rate and Real Cost of Capital, Industry-by-Industry

\begin{tabular}{|c|c|c|c|c|c|}
\hline \multirow[b]{2}{*}{ Industry } & \multirow[b]{2}{*}{$\mathrm{N}$} & \multicolumn{2}{|c|}{ Panel A: Simple Model } & \multicolumn{2}{|c|}{ Panel B: Extended Model } \\
\hline & & Real Growth & Real Cost of Capital & Real Growth & $\begin{array}{r}\text { Real Cost of } \\
\text { Capital } \\
\end{array}$ \\
\hline Agriculture & 122 & $2.92 \%$ & $6.66 \%$ & $1.31 \%$ & $5.23 \%$ \\
\hline Mining & 260 & $10.23 \%$ & $12.82 \%$ & $10.66 \%$ & $13.15 \%$ \\
\hline Manufacturing & 4119 & $4.71 \%$ & $8.08 \%$ & $3.64 \%$ & $7.31 \%$ \\
\hline Utilities & 247 & $6.05 \%$ & $8.87 \%$ & $4.04 \%$ & $7.63 \%$ \\
\hline Construction & 144 & $14.23 \%$ & $19.05 \%$ & $10.96 \%$ & $16.01 \%$ \\
\hline Transportation & 356 & $4.37 \%$ & $7.54 \%$ & $4.62 \%$ & $7.71 \%$ \\
\hline Computers & 515 & $3.64 \%$ & $5.91 \%$ & $1.97 \%$ & $4.56 \%$ \\
\hline Wsale Retail & 443 & $7.06 \%$ & $10.81 \%$ & $5.27 \%$ & $9.29 \%$ \\
\hline Banking Insur & 198 & $4.60 \%$ & $8.58 \%$ & $2.88 \%$ & $7.38 \%$ \\
\hline Real Estate & 356 & $4.35 \%$ & $9.42 \%$ & $1.10 \%$ & $7.19 \%$ \\
\hline Services & 228 & $2.81 \%$ & $5.61 \%$ & $1.86 \%$ & $4.89 \%$ \\
\hline Entertainment & 96 & $5.02 \%$ & $7.48 \%$ & $3.96 \%$ & $6.62 \%$ \\
\hline others & 129 & $12.21 \%$ & $25.19 \%$ & $3.99 \%$ & $23.18 \%$ \\
\hline Mean & 555 & $6.32 \%$ & $10.46 \%$ & $4.33 \%$ & $9.24 \%$ \\
\hline Stdev & 1079 & $3.64 \%$ & $5.67 \%$ & $3.15 \%$ & $5.29 \%$ \\
\hline Minimum & 96 & $2.81 \%$ & $5.61 \%$ & $1.10 \%$ & $4.56 \%$ \\
\hline Lower Quartile & 144 & $4.35 \%$ & $7.48 \%$ & $1.97 \%$ & $6.62 \%$ \\
\hline Median & 247 & $4.71 \%$ & $8.58 \%$ & $3.96 \%$ & $7.38 \%$ \\
\hline Upper Quartile & 356 & $7.06 \%$ & $10.81 \%$ & $4.62 \%$ & $9.29 \%$ \\
\hline Maximum & 4119 & $14.23 \%$ & $25.19 \%$ & $10.96 \%$ & $23.18 \%$ \\
\hline
\end{tabular}

Notes:

Table 7 reports the implied real growth rate and real cost of capital computed on an industry basis. Industry classification follows that of the China Securities Regulatory Commission.

Panel A reports results from using the simple regression model: 


$$
\frac{\text { feps }_{t+1}}{b_{t}}=\delta_{1} \frac{P_{t}}{b_{t}}+\delta_{2} \frac{e_{t}}{b_{t}}+\delta_{3}+\delta_{4} \frac{b_{t-1}}{b_{t}}+\varepsilon_{t+1}, \text { and } g=\frac{\left(1+\delta_{2}+\delta_{3}\right)+\sqrt{\left(1+\delta_{2}+\delta_{3}\right)^{2}-4\left(\delta_{2}-\delta_{4}\right)}}{2}-1, R-1=(1+g)\left(1+\frac{\delta_{1}}{1+g-\delta_{2}}\right)-1 \text {. }
$$

Panel B reports results from using the extended regression model:

$$
\frac{f e p s_{t+1}}{b_{t}}=\delta_{1}^{\prime} \frac{P_{t}}{b_{t}}+\delta_{2}^{\prime} \frac{e_{t}}{b_{t}}+\delta_{3}^{\prime}+\delta_{4}^{\prime} \frac{b_{t-1}}{b_{t}}+\delta_{5}^{\prime} \frac{P_{t-1}}{b_{t}}+\varepsilon_{t+1}^{\prime}, \text { and } g=\frac{1+\delta_{2}^{\prime}+\delta_{3}^{\prime}-\delta_{5}^{\prime}+\sqrt{\left(1+\delta_{2}^{\prime}+\delta_{3}^{\prime}-\delta_{5}^{\prime}\right)^{2}-4\left(\delta_{2}^{\prime}-\delta_{4}^{\prime}-\delta_{5}^{\prime}\right)}}{2}-1, R-1=(1+g)\left(1+\frac{\delta_{1}^{\prime}+\delta_{5}^{\prime}}{1+g-\delta_{2}^{\prime}}\right)-1
$$

feps $_{t+1}$ is the average institutional investor forecasts of earnings per share made around the corresponding reported prior-year earnings announcements; $P_{t}$ and $P_{\mathrm{t}-1}$ are the contemporary equity price and lagged equity price respectively; $b_{t}$ and $b_{t-1}$ are the contemporary book value of equity and lagged book value of equity per share respectively; and $e_{t}$ is the net income before extraordinary items per share. The expected inflation rate is estimated as the geometric mean of the prior 5-year actual CPI inflation rate. Two-way cluster robust standard errors are used to correct for both cross-sectional and time-series dependence. 
Table 8: Sample Descriptive Statistics - U.S Sample

\begin{tabular}{|c|c|c|c|c|c|c|c|c|c|}
\hline stats & feps & $\mathrm{p}$ & bps & eps & dps & $\mathrm{p} / \mathrm{b}$ & $\mathrm{d} / \mathrm{p}$ & roe & mktcap \\
\hline $\mathrm{N}$ & 20117 & 20117 & 20117 & 20117 & 20046 & 20117 & 20046 & 20117 & 20117 \\
\hline mean & 1.10 & 20.76 & 11.41 & 0.95 & 0.35 & 2.49 & 0.02 & 0.07 & 1503000 \\
\hline$s d$ & 1.04 & 15.77 & 10.95 & 1.62 & 0.78 & 2.26 & 0.04 & 0.19 & 2615000 \\
\hline p25 & 0.36 & 8.61 & 4.78 & 0.11 & 0.00 & 1.19 & 0.00 & 0.02 & 179300 \\
\hline median & 0.94 & 17.32 & 9.09 & 0.78 & 0.00 & 1.86 & 0.00 & 0.09 & 540700 \\
\hline p75 & 1.68 & 28.94 & 15.11 & 1.64 & 0.44 & 3.00 & 0.02 & 0.16 & 1596000 \\
\hline \multicolumn{10}{|c|}{ Panel B: Pearson bottom, Spearman top } \\
\hline & feps & $\mathrm{p}$ & bps & eps & dps & $\mathrm{p} / \mathrm{b}$ & $\mathrm{d} / \mathrm{p}$ & roe & mktcap \\
\hline feps & 1.000 & 0.735 & 0.701 & 0.788 & 0.457 & 0.002 & 0.377 & 0.536 & 0.509 \\
\hline $\mathrm{p}$ & 0.692 & 1.000 & 0.662 & 0.728 & 0.398 & 0.343 & 0.304 & 0.510 & 0.719 \\
\hline bps & 0.534 & 0.502 & 1.000 & 0.622 & 0.463 & -0.374 & 0.411 & 0.174 & 0.390 \\
\hline eps & 0.658 & 0.595 & 0.581 & 1.000 & 0.412 & 0.112 & 0.342 & 0.777 & 0.516 \\
\hline dps & 0.308 & 0.299 & 0.417 & 0.393 & 1.000 & -0.090 & 0.979 & 0.199 & 0.286 \\
\hline $\mathrm{p} / \mathrm{b}$ & -0.076 & 0.218 & -0.298 & -0.006 & -0.048 & 1.000 & -0.131 & 0.376 & 0.407 \\
\hline$d / p$ & 0.117 & 0.058 & 0.235 & 0.185 & 0.751 & -0.086 & 1.000 & 0.160 & 0.220 \\
\hline roe & 0.459 & 0.404 & 0.143 & 0.586 & 0.129 & 0.118 & 0.073 & 1.000 & 0.425 \\
\hline mktcap & 0.335 & 0.513 & 0.147 & 0.261 & 0.128 & 0.246 & 0.017 & 0.249 & 1.000 \\
\hline
\end{tabular}

Notes:

Panel A shows descriptive statistics for 20,117 firm-year between 2004 and 2011 based on U.S sample in the intersection of the CRSP, Compustat and I/B/E/S. feps is the median consensus forecasts of earnings per share at the first month after the corresponding I/B/E/S reported prior-year earnings announcements. P, bps, eps, dps are respectively stock price, equity book value per share, earnings per share and dividend per share. mktcap is the market capitalization defined by price multiplied by the number of shares outstanding. Earnings are net income per share before extraordinary items. p/b is the market-to-book ratio. Return on equity (roe) is net income before extraordinary items scaled by lagged book value. $\mathrm{d} / \mathrm{p}$ is dividends scaled by lagged price of equity. Firms with negative book value and in the extreme percentiles with p/b and roe are deleted. The mean, standard deviation (stdev), median and first (Q1) and third (Q3) quartiles are reported. Panel B shows the annual cross-sectional correlations. The upper (lower) right triangle of the matrix shows Spearman (Pearson) correlations. 
Table 9. The implied growth rate, cost of capital and risk premium for the US between 2004-2011

\begin{tabular}{|c|c|c|c|c|c|c|c|c|c|}
\hline \multirow[b]{3}{*}{ Year } & \multirow{3}{*}{$\begin{array}{r}\text { Sample } \\
\text { Size }\end{array}$} & \multirow{3}{*}{$\begin{array}{r}\mathrm{rf} 10 \\
\%\end{array}$} & \multirow{3}{*}{$\begin{array}{r}\text { Inflation } \\
\%\end{array}$} & \multicolumn{2}{|c|}{ Panel A: nominal rate } & \multicolumn{4}{|c|}{ Panel B: real rate } \\
\hline & & & & & Cost of & & & Cost of & \\
\hline & & & & Growth & Capital & $\mathrm{RP}$ & Growth & Capital & $\mathrm{RP}$ \\
\hline 2004 & 2621 & 4.27 & 2.45 & $4.71 \%$ & $7.65 \%$ & $3.38 \%$ & $2.21 \%$ & $5.07 \%$ & $3.30 \%$ \\
\hline 2005 & 2752 & 4.29 & 2.54 & $5.99 \%$ & $8.82 \%$ & $4.53 \%$ & $3.37 \%$ & $6.12 \%$ & $4.42 \%$ \\
\hline 2006 & 2763 & 4.8 & 2.55 & $4.35 \%$ & $7.84 \%$ & $3.04 \%$ & $1.75 \%$ & $5.15 \%$ & $2.96 \%$ \\
\hline 2007 & 2727 & 4.63 & 2.63 & $2.65 \%$ & $7.09 \%$ & $2.46 \%$ & $0.02 \%$ & $4.34 \%$ & $2.39 \%$ \\
\hline 2008 & 2552 & 3.66 & 2.88 & $5.02 \%$ & $8.03 \%$ & $4.37 \%$ & $2.08 \%$ & $5.00 \%$ & $4.25 \%$ \\
\hline 2009 & 2545 & 3.26 & 3.2 & $4.92 \%$ & $10.96 \%$ & $7.70 \%$ & $1.67 \%$ & $7.52 \%$ & $7.46 \%$ \\
\hline 2010 & 2704 & 3.22 & 2.58 & $1.98 \%$ & $6.90 \%$ & $3.68 \%$ & $-0.59 \%$ & $4.21 \%$ & $3.58 \%$ \\
\hline 2011 & 2453 & 2.78 & 2.22 & $3.89 \%$ & $7.56 \%$ & $4.78 \%$ & $1.63 \%$ & $5.23 \%$ & $4.68 \%$ \\
\hline Mean & 2640 & 3.86 & 2.63 & $4.19 \%$ & $8.10 \%$ & $4.24 \%$ & $1.52 \%$ & $5.33 \%$ & $4.13 \%$ \\
\hline Stdev & 114 & 0.74 & 0.29 & $1.32 \%$ & $1.30 \%$ & $1.61 \%$ & $1.25 \%$ & $1.06 \%$ & $1.55 \%$ \\
\hline Minimum & 2453 & 2.78 & 2.22 & $1.98 \%$ & $6.90 \%$ & $2.46 \%$ & $-0.59 \%$ & $4.21 \%$ & $2.39 \%$ \\
\hline Lower Quartile & 2550 & 3.25 & 2.52 & $3.58 \%$ & $7.44 \%$ & $3.29 \%$ & $1.23 \%$ & $4.84 \%$ & $3.21 \%$ \\
\hline Median & 2663 & 3.97 & 2.57 & $4.53 \%$ & $7.74 \%$ & $4.02 \%$ & $1.71 \%$ & $5.11 \%$ & $3.92 \%$ \\
\hline Upper Quartile & 2733 & 4.38 & 2.69 & $4.95 \%$ & $8.23 \%$ & $4.59 \%$ & $2.11 \%$ & $5.45 \%$ & $4.48 \%$ \\
\hline Maximum & 2763 & 4.80 & 3.20 & $5.99 \%$ & $10.96 \%$ & $7.70 \%$ & $3.37 \%$ & $7.52 \%$ & $7.46 \%$ \\
\hline
\end{tabular}

Notes:

Table 9 reports the implied growth rates, cost of capital (COC) and risk premia computed on an annual basis for the US data between 2004-2011. Panels A and B are for nominal and real terms respectively. The extended value-weighted regression model is:

$\frac{f e p s_{t+1}}{b_{t}}=\delta_{1}^{\prime} \frac{P_{t}}{b_{t}}+\delta_{2}^{\prime} \frac{e_{t}}{b_{t}}+\delta_{3}^{\prime}+\delta_{4}^{\prime} \frac{b_{t-1}}{b_{t}}+\delta_{5}^{\prime} \frac{P_{t-1}}{b_{t}}+\varepsilon_{t+1}^{\prime}$, and $g=\frac{1+\delta_{2}^{\prime}+\delta_{3}^{\prime}-\delta_{5}^{\prime}+\sqrt{\left(1+\delta_{2}^{\prime}+\delta_{3}^{\prime}-\delta_{5}^{\prime}\right)^{2}-4\left(\delta_{2}^{\prime}-\delta_{4}^{\prime}-\delta_{5}^{\prime}\right)}}{2}-1, R-1=(1+g)\left(1+\frac{\delta_{1}^{\prime}+\delta_{5}^{\prime}}{1+g-\delta_{2}^{\prime}}\right)-1$.

feps $_{t+1}$ is the median consensus forecasts of earnings in the first month after the corresponding reported prior-year earnings announcements; The risk premium (RP) is calculated relative to calculated relative to the yield on a 10-Year US government bond. The expected inflation rate is estimated as the geometric mean of the prior 5-year actual CPI inflation rate. feps $_{t+1}$ is the median consensus forecasts of earnings in the first month after the corresponding reported prior-year earnings announcements; $P_{t}$ and $P_{\mathrm{t}-1}$ are the contemporary equity price and lagged equity price respectively; $b_{t}$ and $b_{t-1}$ are the contemporary book value of equity and lagged book value of equity per share respectively; and $e_{t}$ is the net income (before extraordinary items) per share. 
Table 10: Country Risk Premium

\begin{tabular}{lrrrrrr} 
& \multicolumn{2}{c}{ Panel A: nominal rate } & & \multicolumn{2}{c}{ Panel B: real rate } & \\
\cline { 2 - 3 } Year & China-RP & US-RP & \multirow{2}{*}{$\begin{array}{l}\text { country risk } \\
\text { premium }\end{array}$} & China-RP & US-RP & \multicolumn{2}{l}{$\begin{array}{l}\text { country risk } \\
\text { premium }\end{array}$} \\
\hline 2004 & $5.66 \%$ & $3.38 \%$ & $2.28 \%$ & $5.60 \%$ & $3.30 \%$ & $2.30 \%$ \\
2005 & $7.74 \%$ & $4.53 \%$ & $3.21 \%$ & $7.64 \%$ & $4.42 \%$ & $3.22 \%$ \\
2006 & $11.66 \%$ & $3.04 \%$ & $8.62 \%$ & $11.49 \%$ & $2.96 \%$ & $8.53 \%$ \\
2007 & $16.71 \%$ & $2.46 \%$ & $14.26 \%$ & $16.29 \%$ & $2.39 \%$ & $13.89 \%$ \\
2008 & $5.56 \%$ & $4.37 \%$ & $1.19 \%$ & $5.37 \%$ & $4.25 \%$ & $1.12 \%$ \\
2009 & $10.43 \%$ & $7.70 \%$ & $2.73 \%$ & $10.17 \%$ & $7.46 \%$ & $2.71 \%$ \\
2010 & $11.82 \%$ & $3.68 \%$ & $8.14 \%$ & $11.48 \%$ & $3.58 \%$ & $7.89 \%$ \\
2011 & $16.65 \%$ & $4.78 \%$ & $11.87 \%$ & $16.06 \%$ & $4.68 \%$ & $11.38 \%$ \\
\hline Mean & $10.78 \%$ & $4.24 \%$ & $6.54 \%$ & $10.51 \%$ & $4.13 \%$ & $6.38 \%$ \\
Stdev & $4.38 \%$ & $1.61 \%$ & $4.89 \%$ & $4.23 \%$ & $1.55 \%$ & $4.72 \%$ \\
Minimum & $5.56 \%$ & $2.46 \%$ & $1.19 \%$ & $5.37 \%$ & $2.39 \%$ & $1.12 \%$ \\
Lower Quartile & $7.22 \%$ & $3.29 \%$ & $2.62 \%$ & $7.13 \%$ & $3.21 \%$ & $2.60 \%$ \\
Median & $11.05 \%$ & $4.02 \%$ & $5.68 \%$ & $10.82 \%$ & $3.92 \%$ & $5.56 \%$ \\
Upper Quartile & $13.03 \%$ & $4.59 \%$ & $9.44 \%$ & $12.63 \%$ & $4.48 \%$ & $9.24 \%$ \\
Maximum & $16.71 \%$ & $7.70 \%$ & $14.26 \%$ & $16.29 \%$ & $7.46 \%$ & $13.89 \%$ \\
\hline
\end{tabular}

Notes:

Table 10 reports the implied risk premia and country risk premium for both China and the US. The country risk premium is defined by the difference between risk premium from the Chinese capital markets and that from the US capital markets over 2004-2011. The risk free rates are the yield on a 10-Year each country's government bond. The expected inflation rate is estimated as the geometric mean of the prior 5-year actual CPI inflation rate for each country. Panels A and B report results in nominal and real term respectively. 